\title{
$-45{ }^{\circ} \mathrm{C}, 106 \mathrm{MPa}$ 水素ガス中における オーステナイト系ステンレス鋼溶接金属の SSRT 特性
}

\author{
松岡 三郎*1，佐藤 豊幸*2，山口 則和*2，濱田 繁*3，中村 眞実*4，松永 久生 ${ }^{* 3}$
}

\section{SSRT properties of austenitic stainless steel weld metals in hydrogen gas at $-45{ }^{\circ} \mathrm{C}$ and $106 \mathrm{MPa}$}

\author{
Saburo MATSUOKA ${ }^{* 1}$, Toyoyuki SATO*2 ${ }^{*}$, Norikazu YAMAGUCHI ${ }^{* 2}$, Shigeru HAMADA*3, \\ Masami NAKAMURA*4 and Hisao MATSUNAGA ${ }^{* 3}$ \\ ${ }^{*} 1,{ }^{4}$ Research center for Hydrogen Industrial Use and Storage, Kyushu University \\ 744 Motooka, Nishi-ku, Fukuoka-shi, Fukuoka 819-0395, Japan \\ ${ }^{* 2}$ TAIYO NIPPON SANSO \\ 3054-3 Shimokurosawa, Takane-cho, Hokuto-shi, Yamanashi 408-0015, Japan \\ ${ }^{* 3}$ Department of Mechanical Engineering, Kyushu University \\ 744 Motooka, Nishi-ku, Fukuoka-shi, Fukuoka 819-0395, Japan
}

\section{Received 21 March 2016}

\begin{abstract}
In order to study the hydrogen embrittlement behavior of austenitic stainless steel weld metals, slow strain rate tensile (SSRT) tests were performed in $106 \mathrm{MPa}$ hydrogen gas at $-45^{\circ} \mathrm{C}$. Tensile specimens, in which whole of the gauge section consists of weld metals, were machined out from a TIG welded round bar. The base metal of multi-pass welded bars was SUS316 (hi-Ni), and the filler metals were 317L, 316 and 316L. The nickel equivalent values of SUS316 (hi-Ni) base metal, and 317L, 316 and 316L weld metals were 29.69, 29.99, 28.87 and 28.27 mass \%, respectively. Two series of weld metals were tested; one was as-welded metal, and the other was post-welded solution-treated weld metal. The relative reduction of area, RRA, was 0.55 for 317L as-welded metal, and approximately 0.9 for SUS316 (hi-Ni) base metal and 317L, 316 and 316L post-welded solution-treated weld metals. The result indicated that the resistance against hydrogen embrittlement was recovered by the post-welded solution-treatment. The fracture surface of SUS316 (hi-Ni) base metal and 317L post-welded solution-treated weld metal was entirely covered with dimples, whereas the fracture surface of 316 and 316L post-welded solution-treated weld metals was covered with dimples and quasi-cleavages. Accordingly, it was concluded that 317L post-welded solution-treated weld metal with the highest nickel equivalent had excellent resistance against hydrogen embrittlement, which was recommended for use in high-pressure hydrogen components.
\end{abstract}

Key words : Austenitic stainless steel weld metals, Hydrogen embrittlement, Relative reduction of area, Post-welded solution-treatment

\section{1. 緒言}

燃料電池自動車が 2014 年 12 月にトヨタ自動車から発売され, $70 \mathrm{MPa}$ 級水素ステーションの建設が大都市圈を 中心に約 100 ケ所で進められている(NEDO 水素エネルギー白書，2014). 水素ガスは約 3 分間で急速充填される が，その際，高圧水素ガスを予冷する必要がある。これに伴い，設計圧力 $106 \mathrm{MPa}$ に対し，水素ガスの最低温度 $-45{ }^{\circ} \mathrm{C}$ が，水素ステーションにおける最も厳しい使用条件として設定されている.このような高圧・低温の水素

No.16-00109 [DOI:10.1299/transjsme.16-00109], J-STAGE Advance Publication date : 7 July, 2016

*1 正員，永年会員，九州大学 水素材料先端科学研究センター（HYDROGENIUS）（干819-0395 福岡県福岡市西区元岡 744）

*2 大陽日酸 (株) (†408-0015 山梨県北杜市高根町下黒澤 3054-3)

*3 正員, 九州大学大学院工学研究院

*4 九州大学 水素材料先端科学研究センター (HYDROGENIUS)

E-mail of corresponding author: nakamura.masami.432@m.kyushu-u.ac.jp 
ガス中で使用できる材料として，一般高圧ガス保安規則の機能性基準の運用（平成 24 年 12 月 26 日）(高圧ガス 協会，2011),(山田，小林，2012)において，二ッケル当量（Ni 当量, 式(1)参照）が 28.5 mass \%以上のオーステナ イト系ステンレス鋼 SUS316（hi-Ni） と SUS316L（hi-Ni）が示されている，一般高圧ガス保安規則の機能性基準 の運用の概要については 3.4 節で後述する. $70 \mathrm{MPa}$ 級水素ステーションで SUS316（hi-Ni） あるいは SUS316L

（hi-Ni）のパイプを接続する場合，水素脆化の少念がある溶接継手ではなく，機械継手であるコーンアンドスレ ッド継手が多く用いられている，コーンアンドスレッド継手に関しては，施工が難しいことや定期的な保守点検 （トルクチェックなど）が必要であることに加えて，水素ガス漏洩の事例も多く報告されている．このような状 況の中，漏洩の心配がない溶接継手を水素ステーションで使用することが強く望まれている．しかし，コーンア ンドスレッド継手の場合には高強度の泠間加工材が使用できるが, 溶接継手の場合には使用できない. そのため, コーンアンドスレッド継手と比較して，溶接継手ではパイプの肉厚が厚くなる.

本研究では，水素ステーションで想定される最低温度と設計圧力の組み合わせ，すなわち $-45{ }^{\circ} \mathrm{C} \cdot 106 \mathrm{MPa}$ の水素ガス中で低歪速度引張試験 (SSRT 試験) を行い, オーステナイト系ステンレス鋼溶接金属 317L, 316, 316L の水素脆性を明らかにする. 過去にオーステナイト系ステンレス鋼の溶接継手を用いた SSRT 試験(平田他, 2013)， (Brooks and West, 1981) と弾塑性破壊勒性試験を行った研究によると，水素によって溶接金属の絞り（RA）と弾塑

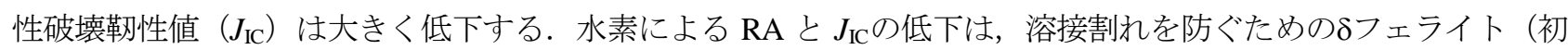
析フェライト）の増加に伴い顕著になると報告されている(Brooks and West, 1981),(Jackson et al., 2012). 本研究で

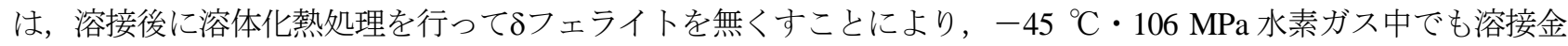
属の RA は低下しないことを示す．これは，70 MPa 級水素ステーションでオーステナイト系ステンレス鋼パイプ を溶接して使用できることを意味する.

\section{2. 実験方法}

これまでに，高圧水素ガス中 SSRT 試験によって，オーステナイト系ステンレス鋼の水素脆化特性が調ベられ ている (井藤賀他, 2013),(Marchi et al., 2010), (山田, 小林, 2012). 高圧水素ガス中 SSRT 試験は ASTM G 142(ASTM, 2011)で規定されている. 図 1 は ASTM G 142 に示されている引張試験片である.この引張試験片をパイプや板の 突合せ溶接継手の溶接金属部分から採取することは困難である，そこで，図 2 に示すように，多層肉盛溶接丸棒 から図 1 の引張試験片を試験部全体（直径 $6 \mathrm{~mm}$, 平行部長さ $30 \mathrm{~mm}$ ）が溶接金属になるように採取した. SSRT 試験には, 多層肉盛溶接を行ったままのものと,多層肉盛溶接後に溶体化熱処理を施したものの 2 種類を供した. 以後，前者を溶接まま試験片，後者を溶体化試験片と呼ぶ.

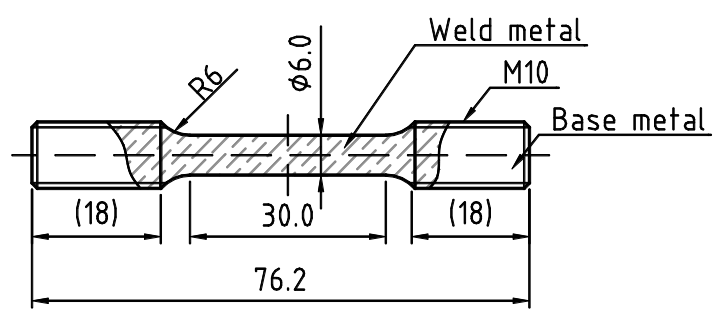

Fig. 1 Tensile specimen (mm).

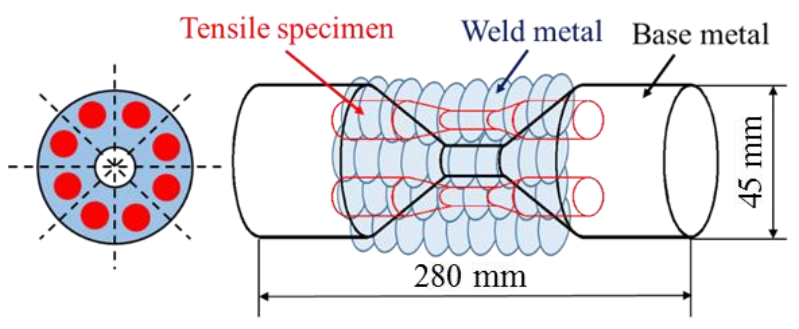

Fig. 2 Multi-pass welded material.

多層肉盛溶接丸棒の母材にはオーステナイト系ステンレス鋼 SUS316（hi-Ni）を用いた. 多層肉盛溶接は，3 種類のオーステナイト系ステンレス鋼溶加材 317L, 316, 316L を用いて, TIG (Tungsten Inert Gas) 溶接で行った. 溶接電流は $120 \mathrm{~A}$ とし, シールガスとして純アルゴンガスを用いた. 表 1 と表 2 に母材と溶加材の化学成分を示 す.ミルシートに記載されている取鍋分析值に加え，母材または溶接金属から採取した試料の化学成分分析によ る製品分析值を示した．なお，製品分析では Cu を分析していない．取鍋分析值と製品分析值はほぼ一致し，ど 
ちらも JIS 規格範囲内であった．表 1 と表 2 には，次式(平山，小切間，1970)で $\mathrm{Ni}$ 当量（mass \%）を計算して示 した.

$$
\text { Nieq }=12.6[\mathrm{C}]+0.35[\mathrm{Si}]+1.05[\mathrm{Mn}]+[\mathrm{Ni}]+0.65[\mathrm{Cr}]+0.98[\mathrm{Mo}]
$$

ここで，[ ]内の元素量の単位は mass \%である. 溶加材 316L の製品分析值による $\mathrm{Ni}$ 当量は，一般高圧ガス保安 規則の機能性基準の運用(高圧ガス協会，2011)に示されている 28.5 mass \%よりわずかに小さくなった．その他の 材料の $\mathrm{Ni}$ 当量は 28.5 mass \%より大きくなった.

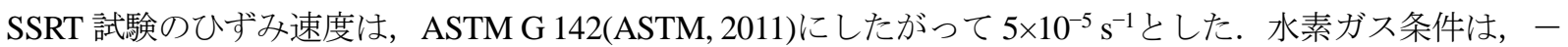
$45{ }^{\circ} \mathrm{C} \cdot 106 \mathrm{MPa}$ とした. 水素ガス純度は $5 \mathrm{~N}$ (99.999\%) である. また, 比較データを取得するために, $-45{ }^{\circ} \mathrm{C} \cdot$ $0.1 \mathrm{MPa}$ 窒素ガス中でも SSRT 試験を行った. SSRT 試験の開始は, 水素ガス条件がー $45{ }^{\circ} \mathrm{C} ・ 106 \mathrm{MPa}$ に設定でき た直後とし，予チャージは行っていない．これは，室温・10000 psi（69 MPa）水素ガス中における低合金鋼 A302, オーステナイト系ステンレス鋼 310, チタン合金 Ti-6Al-4V の SSRT 特性(Walter and Chandler, 1968)に関して，い ずれの供試材に最大 24 時間の予チャージを行っても, SSRT 特性に影響を及ぼさない報告を参考としている.

多層肉盛溶接丸棒の母材と溶接金属の微視組織を電子線後方散乱回折法（EBSD）で調べた。また，SSRT 試験 後の引張試験片の破面を走査型電子顕微鏡（SEM）で観察した.

Table 1 Chemical composition of SUS316 (hi-Ni) base metal (mass \%) and nickel equivalents, Nieq (mass \%).

\begin{tabular}{|c|c|c|c|c|c|c|c|c|c||c|}
\hline & $\mathrm{C}$ & $\mathrm{Si}$ & $\mathrm{Mn}$ & $\mathrm{P}$ & $\mathrm{S}$ & $\mathrm{Ni}$ & $\mathrm{Cr}$ & $\mathrm{Mo}$ & Nieq \\
\hline \multicolumn{2}{|c|}{ Product analysis ${ }^{1)}$} & 0.078 & 0.50 & 1.63 & 0.004 & 0.0015 & 13.38 & 16.87 & 2.53 & 29.69 \\
\hline \multicolumn{2}{|c|}{ Ladle analysis $^{2}$} & 0.070 & 0.48 & 1.74 & 0.004 & 0.003 & 13.53 & 16.95 & 2.51 & 29.88 \\
\hline \multirow{2}{*}{ Requirement $^{2)}$} & min. & - & - & - & - & - & 13.00 & 16.00 & 2.00 & - \\
\cline { 2 - 11 } & max. & 0.080 & 1.00 & 2.00 & 0.045 & 0.030 & 14.00 & 18.00 & 3.00 & - \\
\hline
\end{tabular}

1) Performed by authors

2) JIS G 4303 "Stainless steel bars"

Table 2 Chemical composition of weld metals (mass \%) and nickel equivalents, Nieq (mass \%).

(a) $317 \mathrm{~L}$ weld metal

\begin{tabular}{|c|c|c|c|c|c|c|c|c|c|c||c|}
\hline & $\mathrm{C}$ & $\mathrm{Si}$ & $\mathrm{Mn}$ & $\mathrm{P}$ & $\mathrm{S}$ & $\mathrm{Ni}$ & $\mathrm{Cr}$ & $\mathrm{Mo}$ & $\mathrm{Cu}$ & Nieq \\
\hline \multicolumn{2}{|c|}{ Product analysis $^{1)}$} & 0.009 & 0.46 & 1.57 & 0.023 & 0.0025 & 12.91 & 18.73 & 3.04 & - & 29.99 \\
\hline \multicolumn{2}{|c|}{ Ladle analysis $^{2}$} & 0.011 & 0.44 & 1.56 & 0.024 & 0.002 & 13.06 & 18.59 & 3.04 & 0.14 & 30.05 \\
\hline \multirow{2}{*}{ Requirement $^{2)}$} & min. & - & - & 1.00 & - & - & 13.00 & 18.50 & 3.00 & - & - \\
\cline { 2 - 12 } & max. & 0.030 & 0.65 & 2.50 & 0.030 & 0.030 & 15.00 & 20.50 & 4.00 & 0.75 & - \\
\hline
\end{tabular}

(b) 316 weld metal

\begin{tabular}{|c|c|c|c|c|c|c|c|c|c|c||c|}
\hline & $\mathrm{C}$ & $\mathrm{Si}$ & $\mathrm{Mn}$ & $\mathrm{P}$ & $\mathrm{S}$ & $\mathrm{Ni}$ & $\mathrm{Cr}$ & $\mathrm{Mo}$ & $\mathrm{Cu}$ & Nieq \\
\hline \multicolumn{2}{|c|}{ Product analysis $^{1)}$} & 0.032 & 0.47 & 1.62 & 0.024 & 0.0010 & 12.14 & 19.10 & 2.19 & - & 28.97 \\
\hline \multicolumn{2}{|c|}{ Ladle analysis $^{2}$} & 0.036 & 0.47 & 1.54 & 0.023 & 0.001 & 12.07 & 18.93 & 2.10 & 0.26 & 28.67 \\
\hline \multirow{2}{*}{ Requirement $^{2)}$} & min. & - & - & 1.00 & - & - & 11.00 & 18.00 & 2.00 & - & - \\
\cline { 2 - 12 } & max. & 0.08 & 0.65 & 2.50 & 0.030 & 0.030 & 14.00 & 20.00 & 3.00 & 0.75 & - \\
\hline
\end{tabular}

1) Performed by authors

2) JIS Z 3221 "Stainless steel rods, wires and strip electrodes for welding" 
Matsuoka, Sato, Yamaguchi, Hamada, Nakamura and Matsunaga,

Transactions of the JSME (in Japanese), Vol.82, No.839 (2016)

Table 2 Chemical composition of weld metals (mass \%) and nickel equivalents, Nieq (mass \%).

(c) $316 \mathrm{~L}$ weld metal

\begin{tabular}{|c|c|c|c|c|c|c|c|c|c|c||c|}
\hline & $\mathrm{C}$ & $\mathrm{Si}$ & $\mathrm{Mn}$ & $\mathrm{P}$ & $\mathrm{S}$ & $\mathrm{Ni}$ & $\mathrm{Cr}$ & $\mathrm{Mo}$ & $\mathrm{Cu}$ & Nieq \\
\hline \multicolumn{2}{|c|}{ Product analysis $^{1)}$} & 0.009 & 0.41 & 1.58 & 0.024 & 0.0010 & 12.20 & 18.56 & 2.13 & - & 28.27 \\
\hline \multicolumn{2}{|c|}{ Ladle analysis $^{2}$} & 0.010 & 0.41 & 1.57 & 0.024 & 0.002 & 12.35 & 18.77 & 2.08 & 0.16 & 28.51 \\
\hline \multirow{2}{*}{ Requirement $^{2)}$} & min. & - & - & 1.00 & - & - & 11.00 & 18.00 & 2.00 & - & - \\
\cline { 2 - 12 } & max. & 0.030 & 0.35 & 2.50 & 0.030 & 0.030 & 14.00 & 20.00 & 3.00 & 0.75 & - \\
\hline
\end{tabular}

1) Performed by authors

2) JIS Z 3221 "Stainless steel rods, wires and strip electrodes for welding"

\section{3. 実験結果と考察}

\section{$3 \cdot 1$ 組織の EBSD 像}

図 3 に多層肉盛溶接丸棒の母材 SUS316（hi-Ni）の組織の EBSD 像を示寸. 図 4 7 に多層肉盛溶接丸棒の溶接 金属の組織の EBSD 像を示す. 図 4 は溶加材 317L で溶接したままの組織であり, 図 5７ は溶加材 317L，316, 316L で溶接した後に溶体化熱処理した組織である. 図 3(a)の低倍率 IPF (Inverse Pole Figure)に示すように, SUS316

(hi-Ni) の母材組織は細粒の等軸晶であったのに対して，図 4(a)に示した 317L の溶接まま組織は粗粒の柱状晶 であった．図 4(c)の高倍率 PHASE において, 緑色部は $\gamma$ 相，赤色部は $\alpha$ 相を示す. この $\alpha$ 相は, 過去に水素脆化特

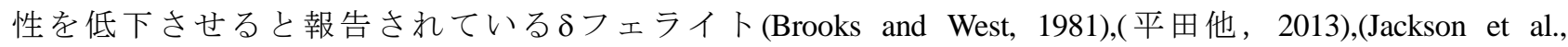
2012),(Somerday et al., 2009)である. 317L，316，316L 溶接後溶体化組織は等軸晶であったが，図 3(a)の低倍率 IPF で示した SUS316（hi-Ni）母材組織 に比べ, 粗粒になっていた. また, 図 5(c)〜7(c)に示した高倍率の PHASE においても, 検出されなかった。

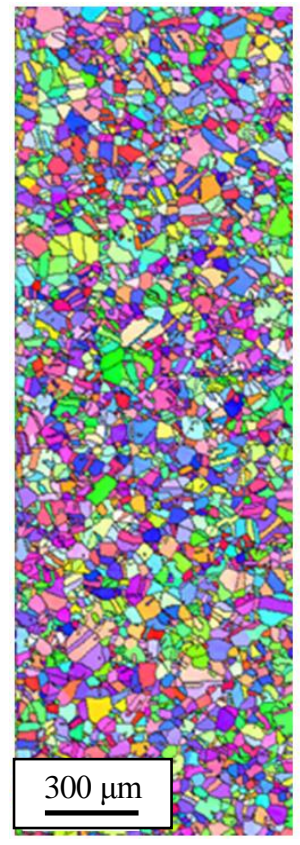

(a) Low magnification IPF

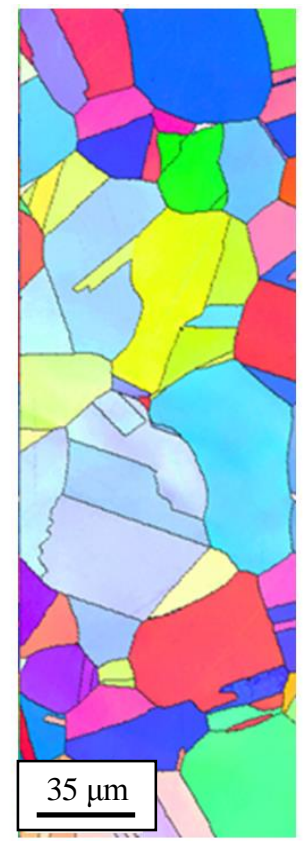

(b) High magnification IPF
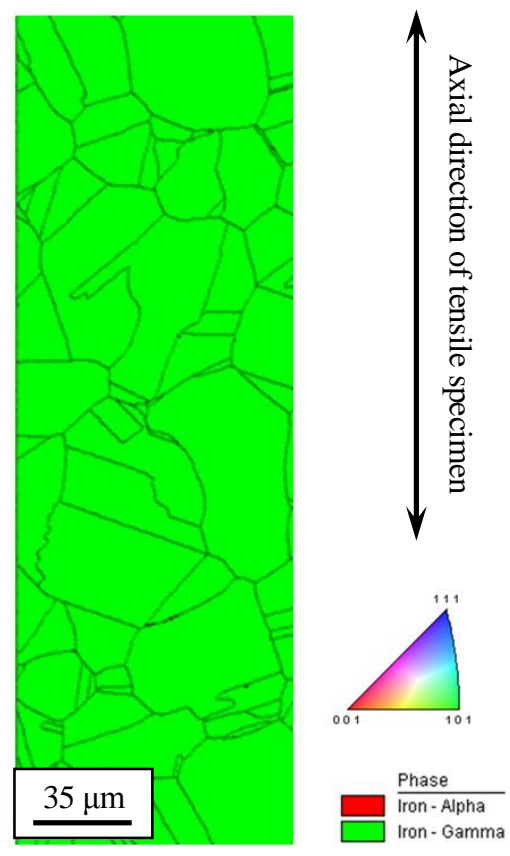

(c) High magnification PHASE

Fig. 3 EBSD images of SUS316 (hi-Ni) base metal. 
Matsuoka, Sato, Yamaguchi, Hamada, Nakamura and Matsunaga,

Transactions of the JSME (in Japanese), Vol.82, No.839 (2016)

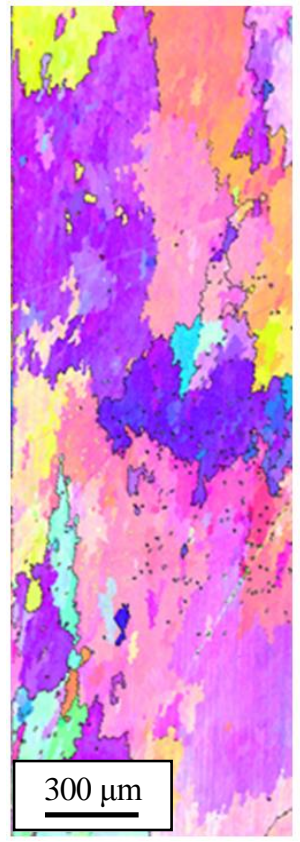

(a) Low magnification IPF

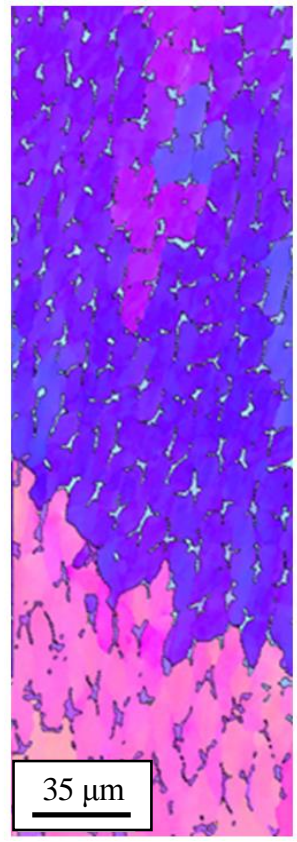

(b) High magnification IPF

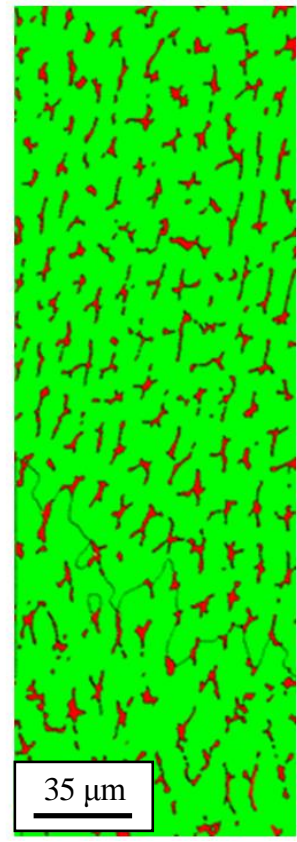

(c) High magnification PHASE

Fig.4 EBSD images of 317L as-welded metal.

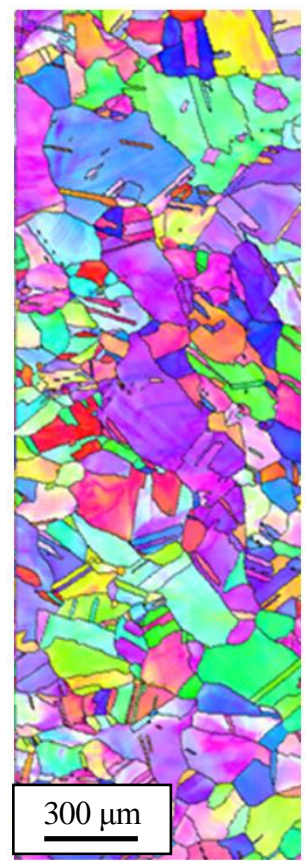

(a) Low magnification IPF

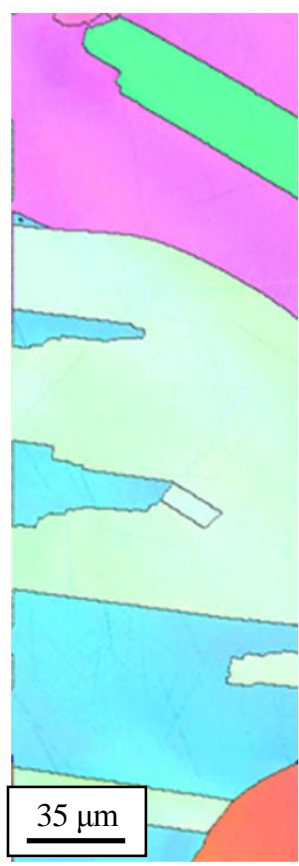

(b) High magnification IPF

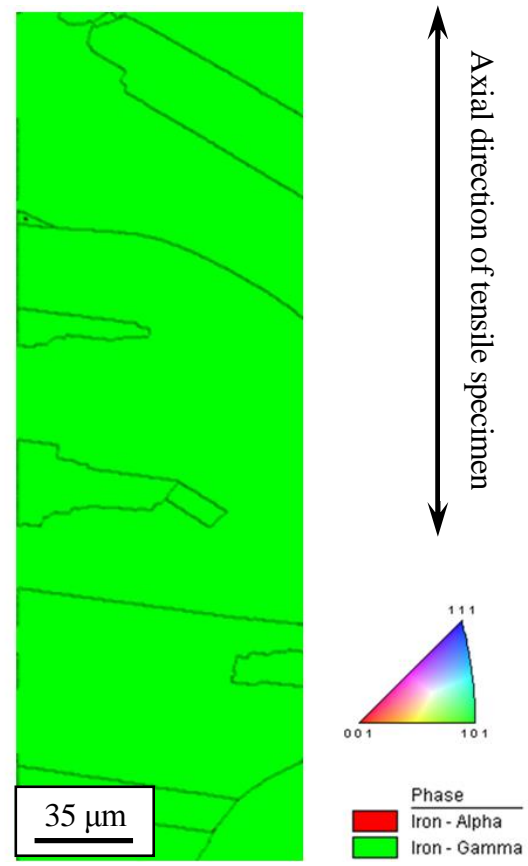

(c) High magnification PHASE

Fig.5 EBSD images of 317L post-welded solution-treated weld metal. 
Matsuoka, Sato, Yamaguchi, Hamada, Nakamura and Matsunaga,

Transactions of the JSME (in Japanese), Vol.82, No.839 (2016)

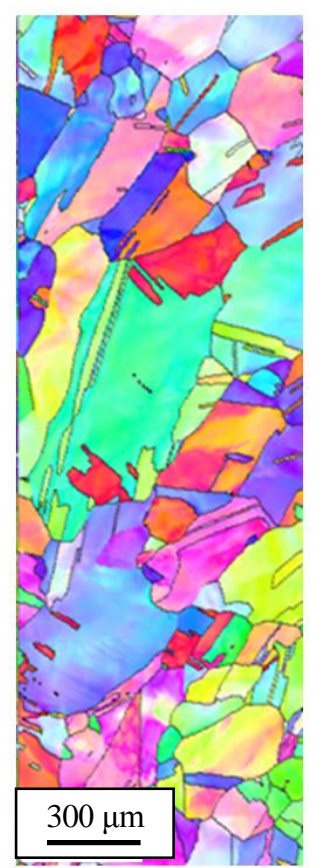

(a) Low magnification

IPF

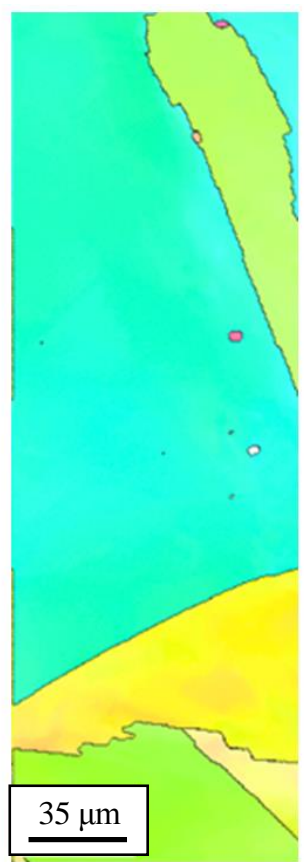

(b) High magnification IPF

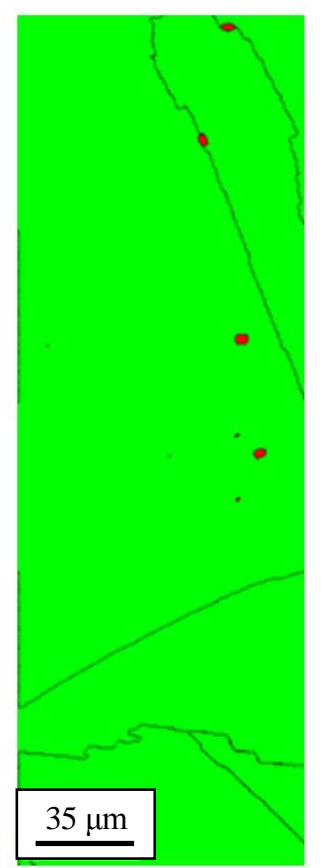

(c) High magnification PHASE

Fig.6 EBSD images of 316 post-welded solution-treated weld metal.

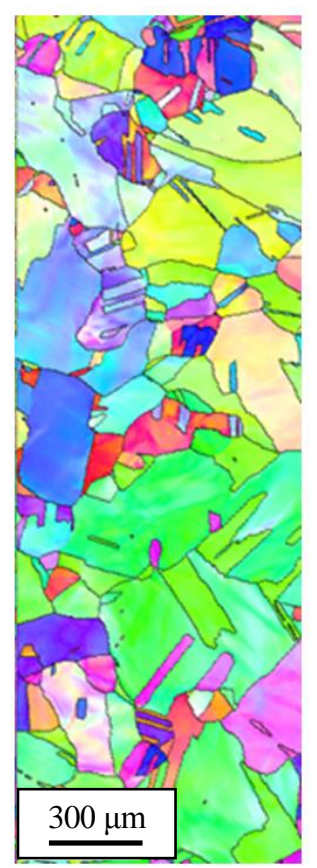

(a) Low magnification IPF

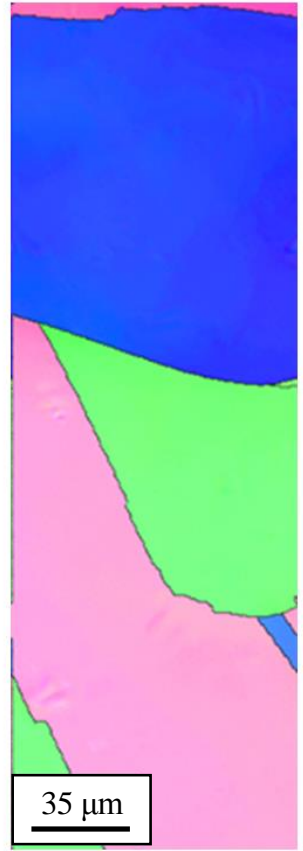

(b) High magnification IPF
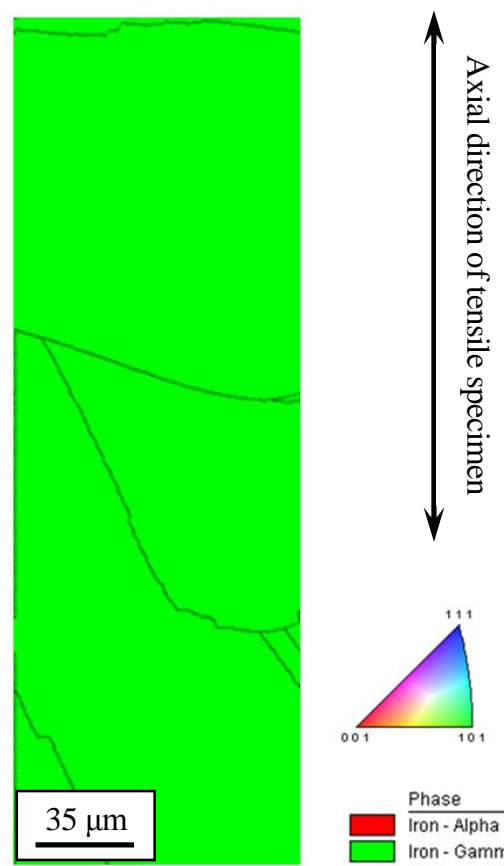

Phase

Iron-Alpha 


\section{$3 \cdot 2$ 応カー変位曲線}

図 8 に, SUS316（hi-Ni） 母材試験片の SSRT 試験で得られた応力ーストローク変位曲線を示す。 $-45{ }^{\circ} \mathrm{C} ・ 0.1$ $\mathrm{MPa}$ 窒素ガス中では，引張強さ $\sigma_{\mathrm{B}, \mathrm{N}}=756 \mathrm{MPa} ，$ 絞り $\varphi_{\mathrm{N}}=83 \%$ であったのに対し， $-45{ }^{\circ} \mathrm{C} \cdot 106 \mathrm{MPa}$ 水素ガス 中では， $\sigma_{\mathrm{B}, \mathrm{H}}=734 \mathrm{MPa} ， \varphi_{\mathrm{H}}=85 \%$ となり，引張強さと絞りの低下は見られなかった．過去の研究においても， $\mathrm{Ni}$ 当量が高く安定なオーステナイト組織を有する SUS316（hi-Ni） は，高圧水素ガス環境中において良好な耐水 素性を示すことが報告されている(Matsuoka et al., 2016).

図 9 に，溶接まま材の試験結果の例として，317L 溶接まま試験片の応力ーストローク変位曲線を示す．前述の ように, 使用した引張試験片の試験部全体（直径 $6 \mathrm{~mm}$, 平行部長さ $30 \mathrm{~mm}$ ) が溶接金属である. $-45{ }^{\circ} \mathrm{C} \cdot 0.1 \mathrm{MPa}$ 窒素ガス中では， $\sigma_{\mathrm{B}, \mathrm{N}}=726 \mathrm{MPa} ， \varphi_{\mathrm{N}}=58 \%$ であった. 図 8 の SUS316（hi-Ni）母材試験片と比べると, 317L 溶

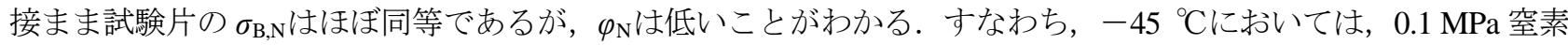
ガスのような不活性ガス中でも，317L 溶接金属の延性は SUS316（hi-Ni）母材に比べて劣る．一方， $-45{ }^{\circ} \mathrm{C} \cdot$ $106 \mathrm{MPa}$ 水素ガス中では， $\sigma_{\mathrm{B}, \mathrm{H}}=692 \mathrm{MPa}, \varphi_{\mathrm{H}}=32 \%$ \%゙った. 窒素ガス中に比べて, 水素ガス中において引張強 さはほとんど低下しなかったが，絞りはほぼ半分に低下した．水素脆化の指標として，相対絞り $\mathrm{RRA}=\varphi_{\mathrm{H}} / \varphi_{\mathrm{N}}$ が 広く用いられている(井藤賀他, 2013),(Marchi et al., 2010),(山田, 小林, 2012). 317L 溶接まま試験片では, RRA = 0.55 となった．また，SUS316（hi-Ni）母材試験片の $\varphi_{\mathrm{N}}=83 \%$ 用いると，RRA=0.38 となる．すなわち，溶接状態 ままの 317L 溶接金属の延性は， $-45{ }^{\circ} \mathrm{C} ・ 106 \mathrm{MPa}$ の水素ガス中において大きく低下する.

図 10 に，317L，316，316L 溶体化試験片の応力ーストローク変位曲線を示す. 図 9 の 317L 溶接まま試験片 の結果と図 10(a)の 317L 溶体化試験片の結果を比べると, $-45{ }^{\circ} \mathrm{C} ・ 0.1 \mathrm{MPa}$ 窒素ガス中のみならず, $-45{ }^{\circ} \mathrm{C} \cdot$ $106 \mathrm{MPa}$ 水素ガス中においても, 破断伸びは溶接後の溶体化熱処理により約 2.5 倍大きくなっていることがわか る.これに対応し, 絞りも大幅に大きくなり, 窒素ガス中で $\varphi_{\mathrm{N}}=84 \%$, 水素ガス中で $\varphi_{\mathrm{H}}=76 \%$ となり, RRA $=0.90$ となった．このことは，溶接後の溶体化熱処理で 317L 溶接金属はほとんど水素脆化しなくなったことを示して いる. 同様な傾向は, 図 10(b)の 316 溶体化試験片, 図 10(c)の 316L 溶体化試験片においても確認された. 相対絞 りは，316 溶体化試験片で RRA $=0.90 ， 316 \mathrm{~L}$ 溶体化試験片で RRA = 0.87であった.

一方，317L，316，316L 溶体化試験片の 0.2\%耐力および引張強さは，いずれも溶接まま試験片と比較して低下 していた．これは，図 5〜7 の EBSD 像に示されているように，溶接後溶体化熱処理によって結晶粒が粗大化し たことに起因寸る. 高圧ガス保安法の特定設備検査規則(高圧ガス協会, 2011)における規定最小引張強さは,

SUS316 で520 MPa，SUS317L および SUS316L で 480 MPa とされ，また，JIS G 4303(JIS，2014)における降伏応 力と引張強さは, SUS316 で $205 \mathrm{MPa}$ 以上と $520 \mathrm{MPa}$ 以上, SUS317L および SUS316L で $175 \mathrm{MPa}$ 以上と $480 \mathrm{MPa}$ 以上とされている. これらの強度基準に対して, 図 8～10に示すように, 317L, 316, 316L 溶体化試験片の $0.2 \%$ 耐力と引張強さはいずれも高圧ガス保安法特定設備検査規則および JIS 規格を満たしていた.

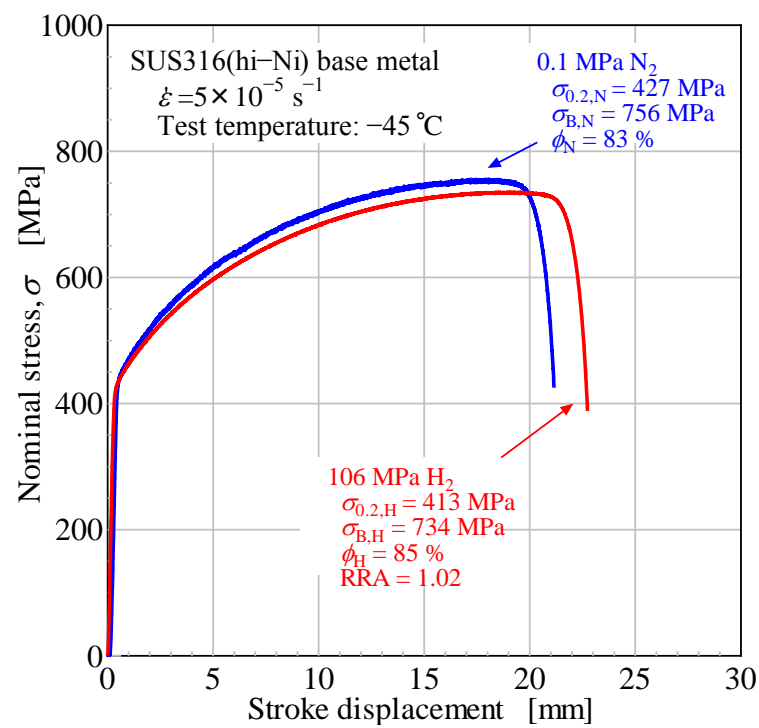

Fig. 8 Stress-displacement curve of SUS316 (hi-Ni) base metal.

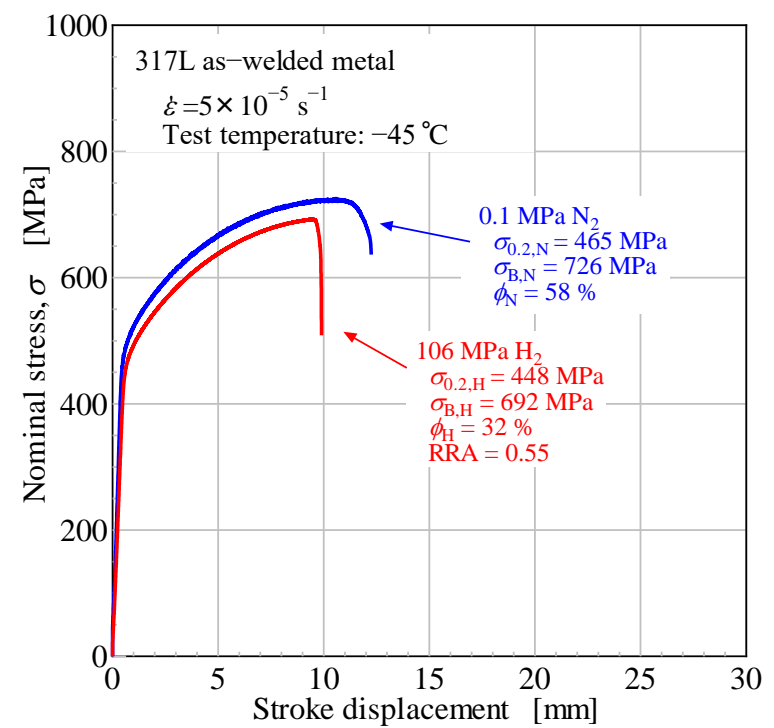

Fig. 9 Stress-displacement curve of 317L as-welded metal. 


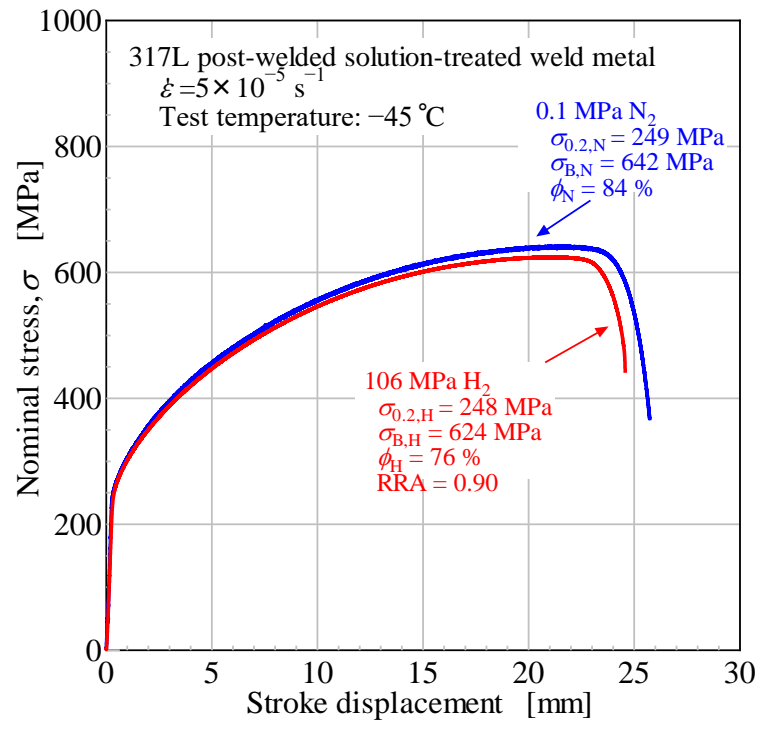

(a) $317 \mathrm{~L}$

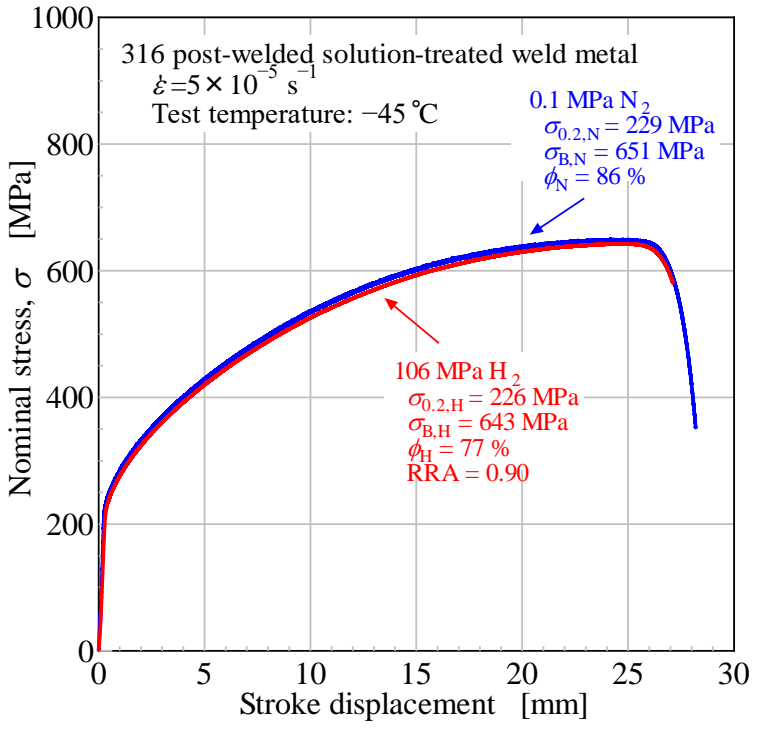

(b) 316

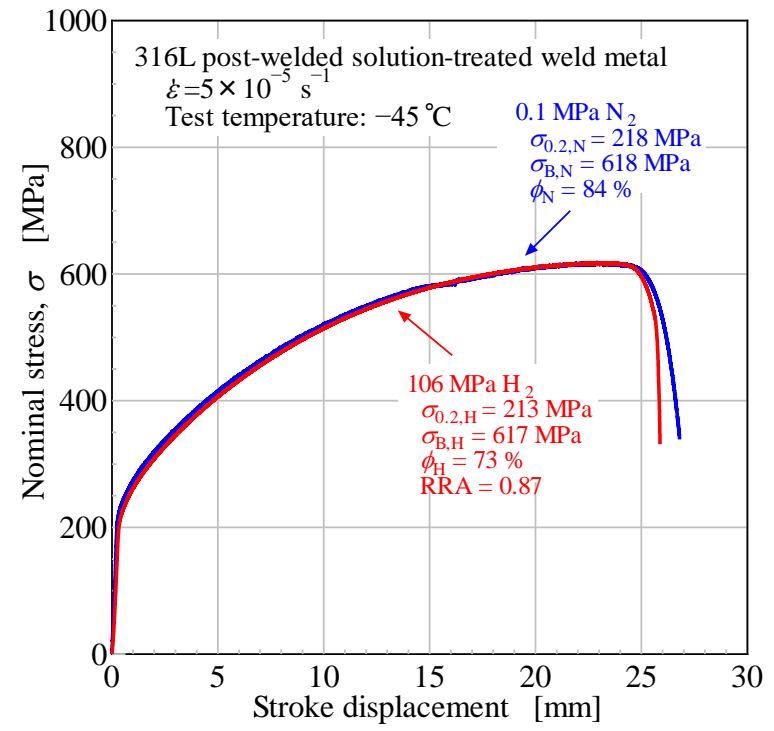

(c) $316 \mathrm{~L}$

Fig. 10 Stress-displacement curves of post-welded solution-treated weld metals. The relative reduction of area, RRA, of 317L as-welded metal was 0.55 , whereas that of 317L post-welded solution-treated weld metal was 0.90 as well as SUS316 (hi-Ni) base metal. The result indicated that the resistance of $317 \mathrm{~L}$ weld metal against hydrogen embrittlement was recovered to that of SUS316 (hi-Ni) base metal by the post-welded solution-treatment. 316 and 316L weld metal also showed the trend similar to $317 \mathrm{~L}$ weld metal. 


\section{3 - 3 引張破面}

図 11 に, SUS316（hi-Ni）母材試験片の引張破面の SEM 像を示す. $-45{ }^{\circ} \mathrm{C} ・ 0.1 \mathrm{MPa}$ 窒素ガス中とー45 ${ }^{\circ} \mathrm{C} ・$ $106 \mathrm{MPa}$ 水素ガス中のいずれにおいても，マクロ破壊形態は明瞭なカップアンドコーン破壊であった。 ミクロ的 には破面の全体はディンプル（D）であった.

図 12 に 317L 溶接まま試験片の引張破面の SEM 像を示す。 - $45{ }^{\circ} \mathrm{C} ・ 0.1 \mathrm{MPa}$ 窒素ガス中では, マクロ破壊形 態は明瞭なカップアンドコーンとはならなかったものの，ミクロ的には破面は全体がディンプルで覆われていた

(図 12(a)）。-45 ${ }^{\circ} \mathrm{C} ・ 106 \mathrm{MPa}$ 水素ガス中では，破面は擬へき開領域（QC）とディンプル領域（D）に分かれて いた (図 12(b))。水素ガス中で擬へき開領域が形成されたことに伴い, 図 9 に示したように，絞りが大幅に低下 したと考えられる。このような擬へき開領域は，引張過程において，表面き裂の発生と進展が水素で助長される ことにより生じることが，これまでの著者らの研究で明らかになっている(Matsunaga et al., 2015a, 2015b).また， 擬へき開領域には縦割れが形成されていた。縦割れは溶接による柱状晶（図 4）と関係すると考えられる.

図 13〜15 に, 317L，316，316L 溶体化試験片の引張破面の SEM 像を示す. $-45{ }^{\circ} \mathrm{C} ・ 0.1 \mathrm{MPa}$ 窒素ガス中では, 317L，316，316L 溶体化試験片は全てカップアンドコーン破壊し，破面はディンプルで覆われていた（図 13(a), 図 14(a), 図 15(a))。-45 ${ }^{\circ} \mathrm{C} ・ 106 \mathrm{MPa}$ 水素ガス中では，317L 溶体化試験片はカップアンドコーン破壊し，破面 はディンプルで覆われていた (図 13(b))。しかし，316 と 316L の溶体化試験片はカップアンドコーン破壊の形態 を示したものの，破面にはディンプル領域に加えて擬へき開領域も形成され，さらに試験片表面には 2 次き裂が 残されていた（図14(b), 図15(b)).

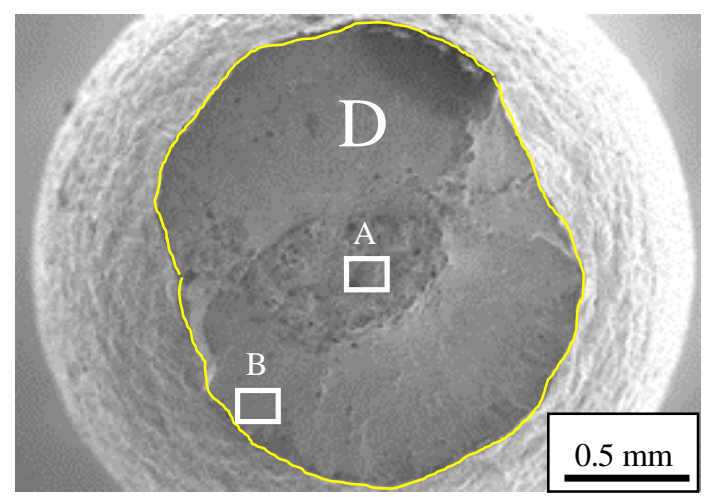

(a1) Top view

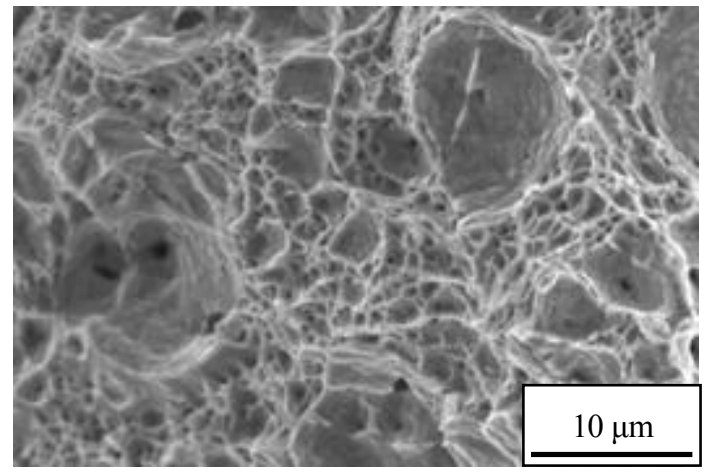

(a3) Magnification of A

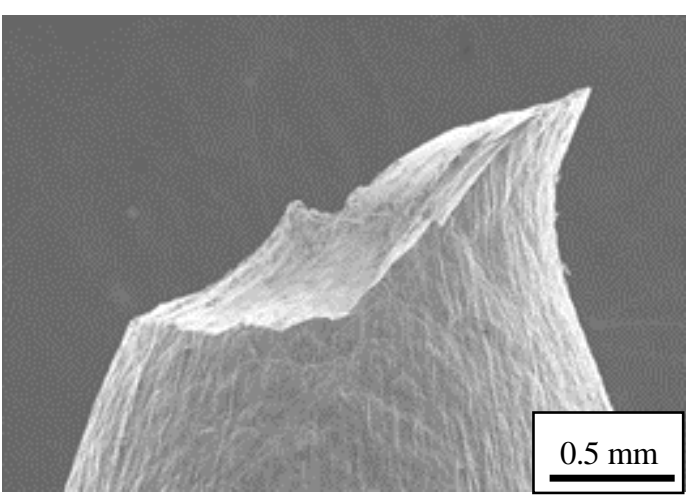

(a2) Side view

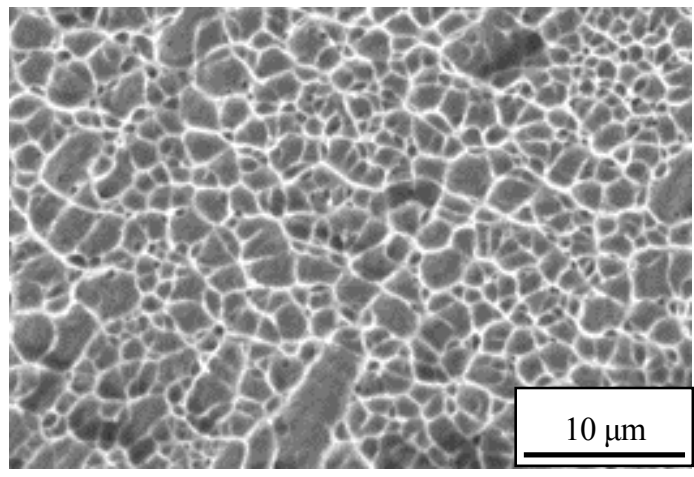

(a4) Magnification of B

(a) In $0.1 \mathrm{MPa}$ nitrogen gas at $-45{ }^{\circ} \mathrm{C}$

Fig. 11 SEM images of SUS316 (hi-Ni) base metal. 
Matsuoka, Sato, Yamaguchi, Hamada, Nakamura and Matsunaga,

Transactions of the JSME (in Japanese), Vol.82, No.839 (2016)

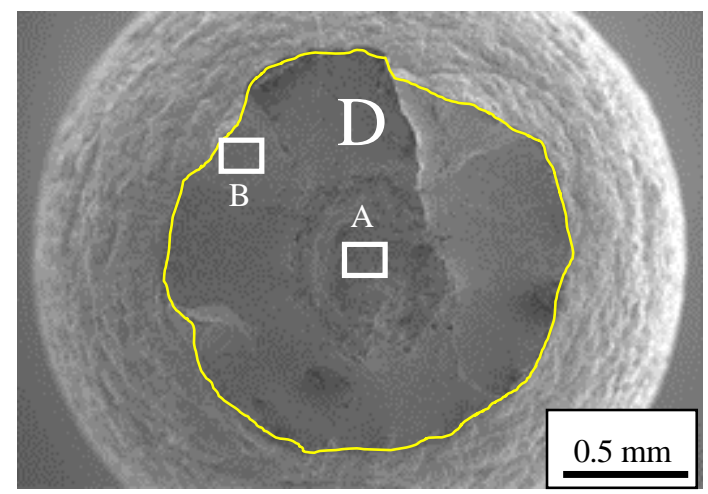

(b1) Top view

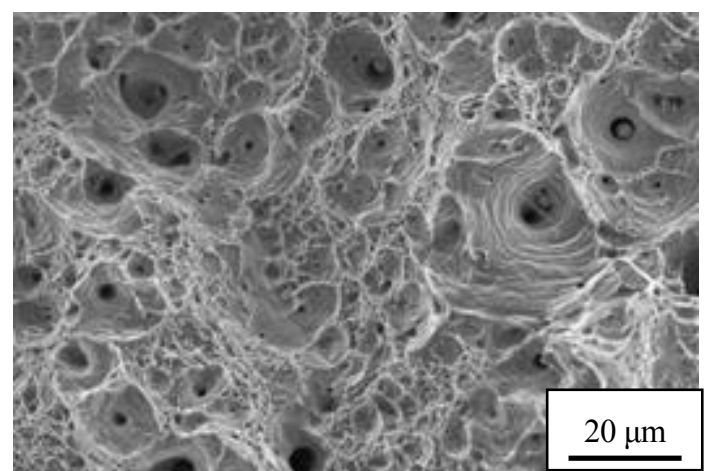

(b3) Magnification of A

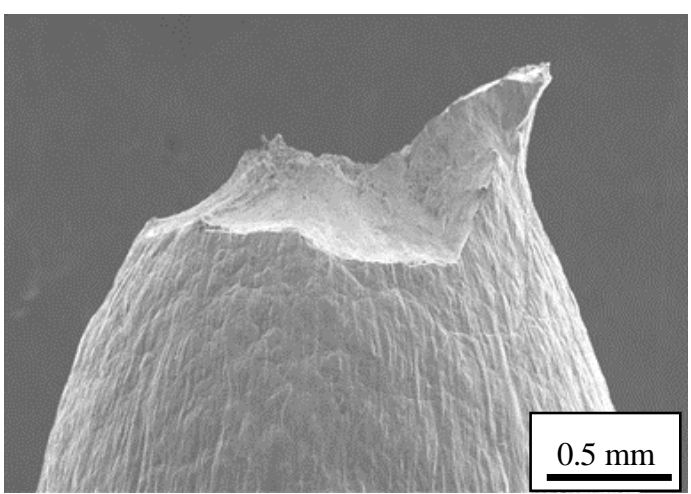

(b2) Side view

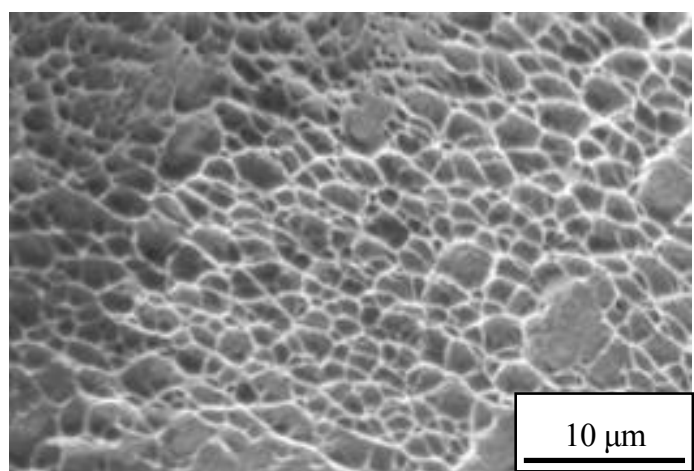

(b4) Magnification of B

(b) In 106 MPa hydrogen gas at $-45{ }^{\circ} \mathrm{C}$

Fig. 11 SEM images of SUS316 (hi-Ni) base metal.

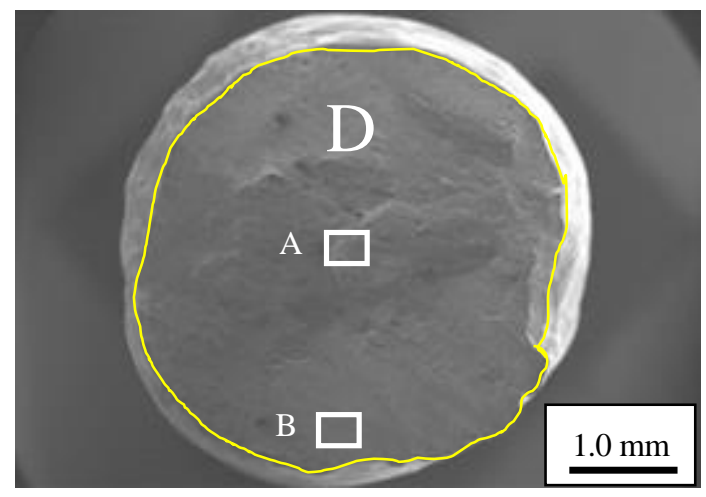

(a1) Top view

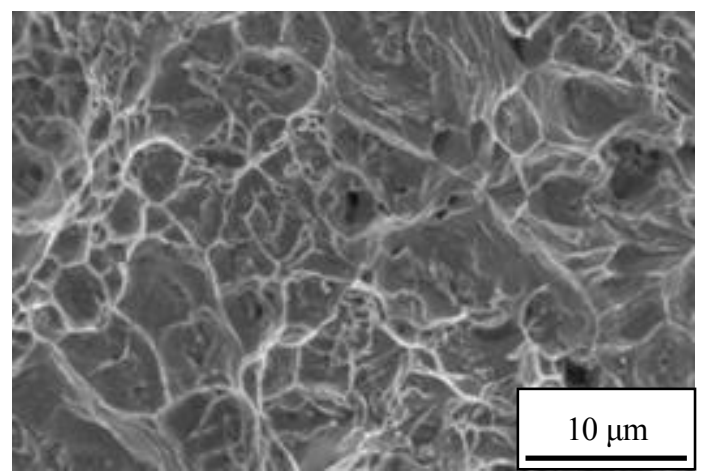

(a3) Magnification of A

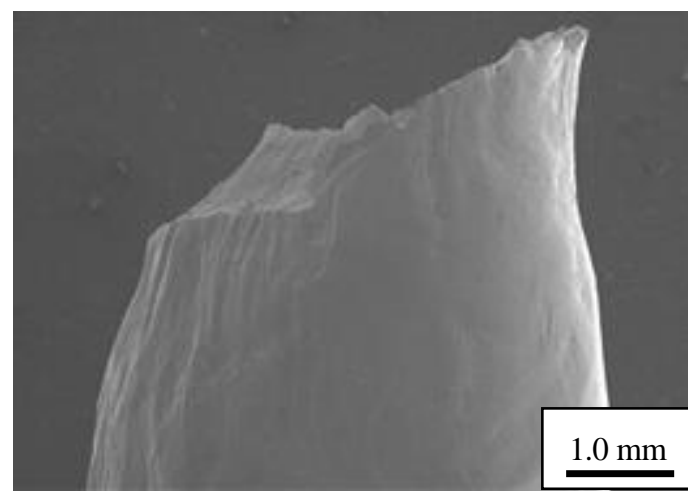

(a2) Side view

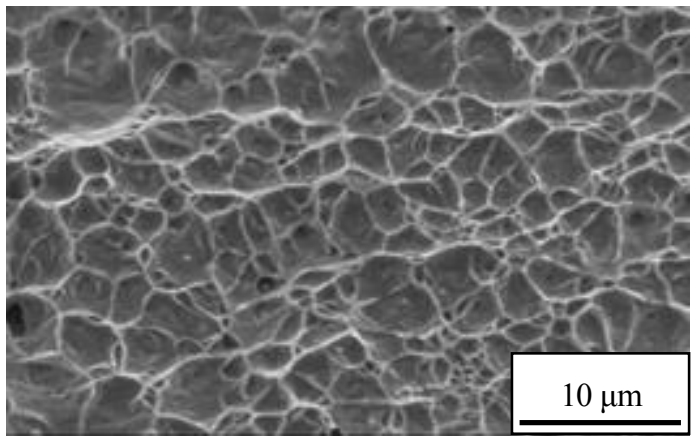

(a4) Magnification of B

(a) In $0.1 \mathrm{MPa}$ nitrogen gas at $-45{ }^{\circ} \mathrm{C}$

Fig. 12 SEM images of 317L as-welded metal. 
Matsuoka, Sato, Yamaguchi, Hamada, Nakamura and Matsunaga,

Transactions of the JSME (in Japanese), Vol.82, No.839 (2016)

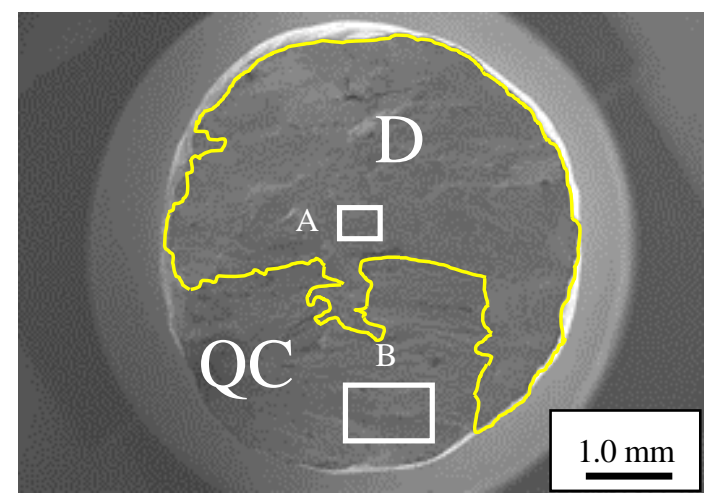

(b1) Top view

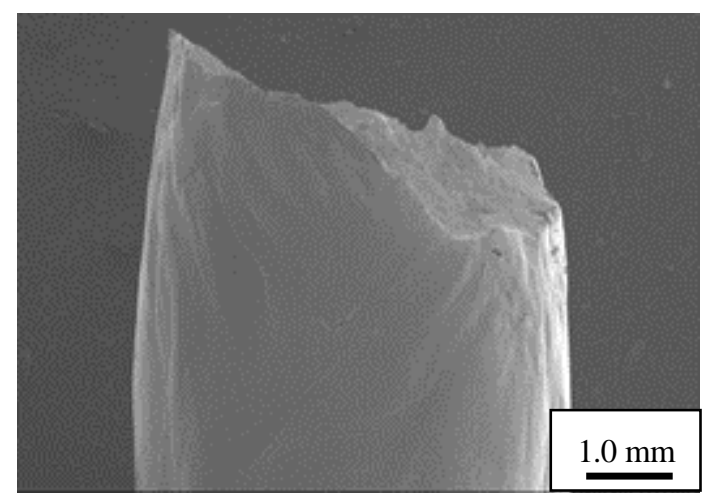

(b2) Side view

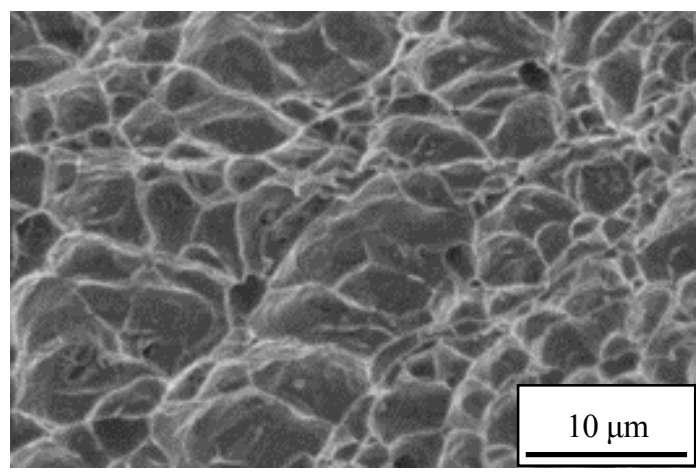

(b3) Magnification of A in Fig. (b1)

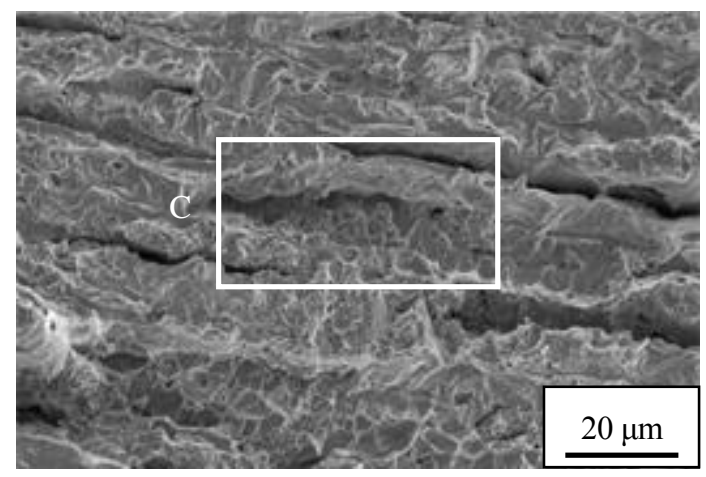

(b4) Magnification of B in Fig. (b1)

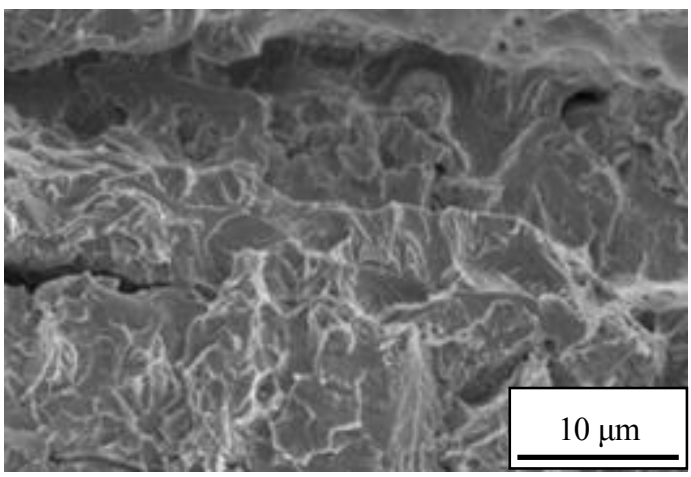

(b5) Magnification of C in Fig. (b4)

(b) In106 MPa hydrogen gas at $-45{ }^{\circ} \mathrm{C}$

Fig. 12 SEM images of 317L as-welded metal. 


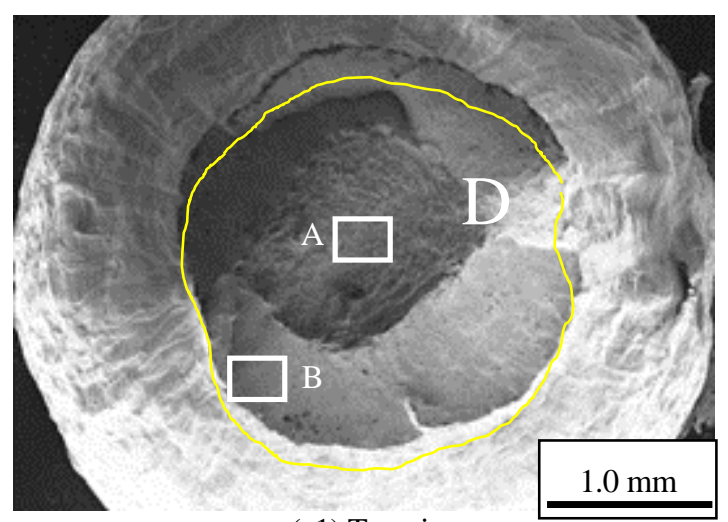

(a1) Top view

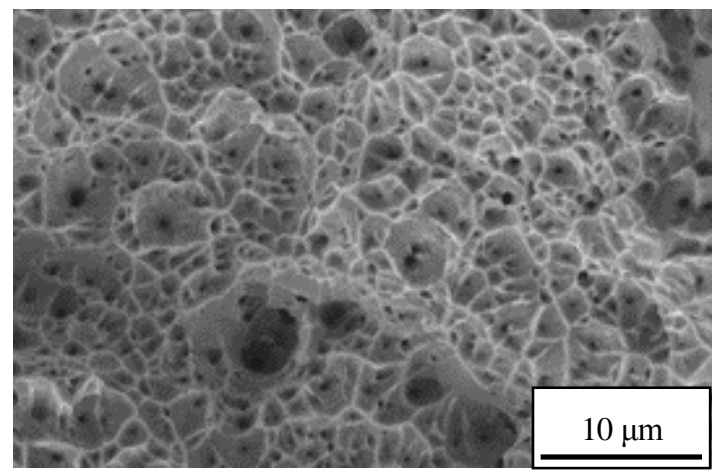

(a3) Magnification of A

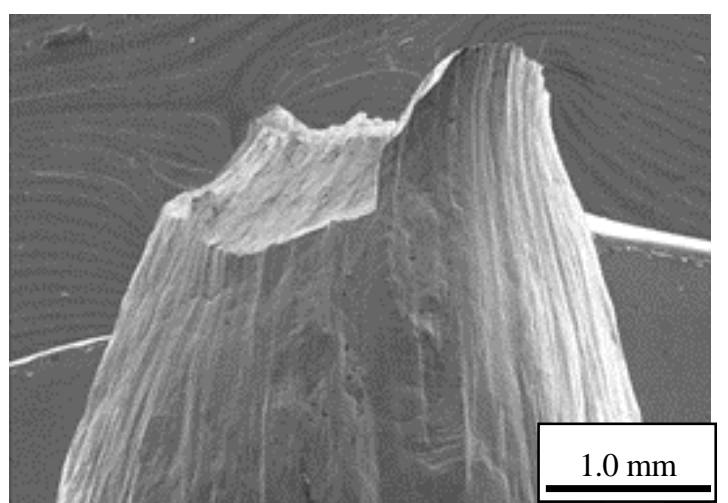

(a2) Side view

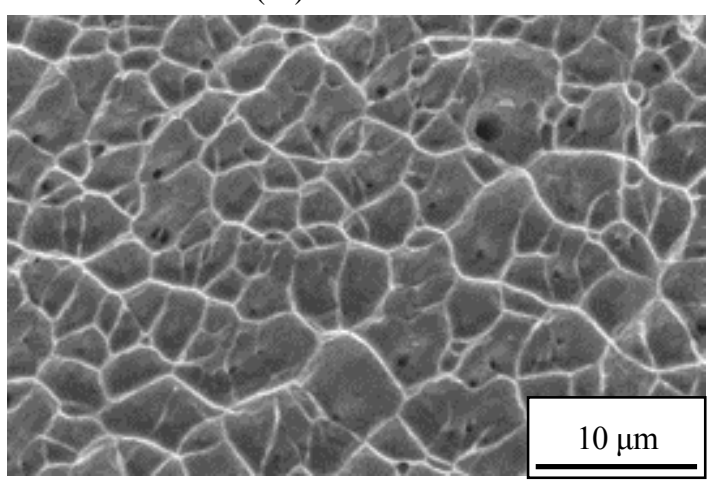

(a4) Magnification of B

(a) In 0.1 MPa nitrogen gas at $-45{ }^{\circ} \mathrm{C}$

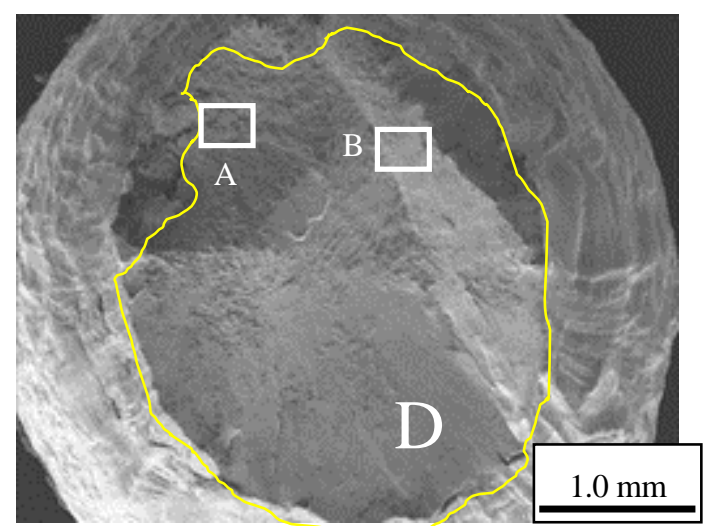

(b1) Top view

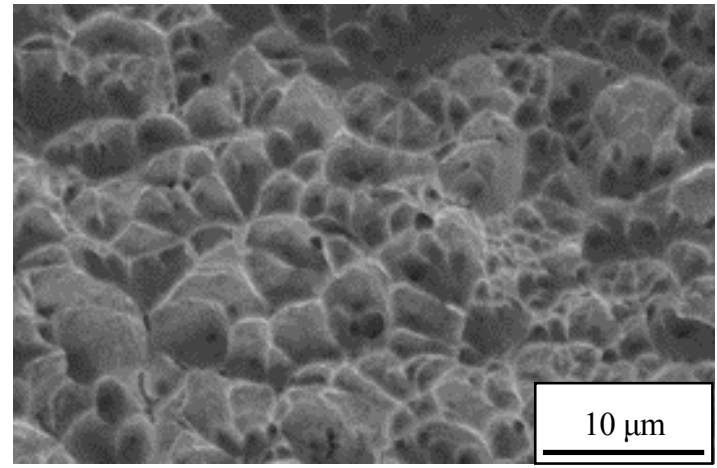

(b3) Magnification of A

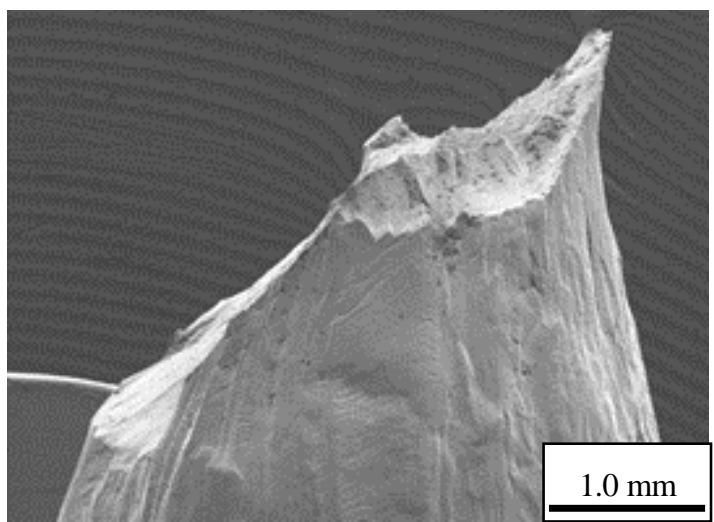

(b2) Side view

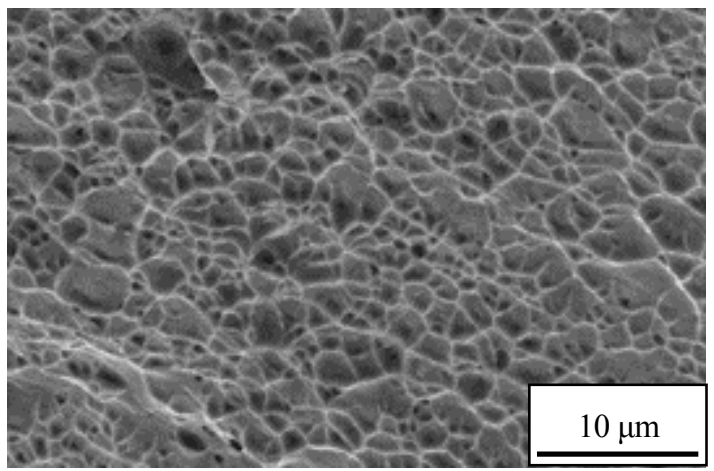

(b4) Magnification of B

(b) In $106 \mathrm{MPa}$ hydrogen gas at $-45{ }^{\circ} \mathrm{C}$

Fig. 13 SEM images of 317L post-welded solution-treated weld metal. The fracture surface of 317L post-welded solution-treated weld metal was entirely covered with dimples in contract to that of $317 \mathrm{~L}$ as-welded metal. 


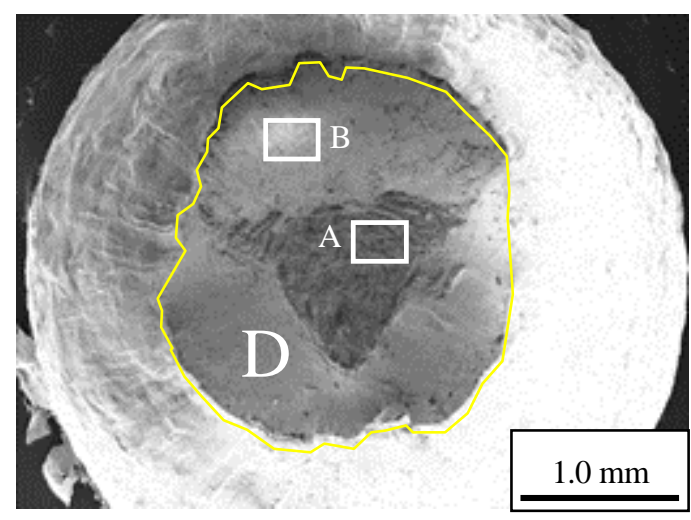

(a1) Top view

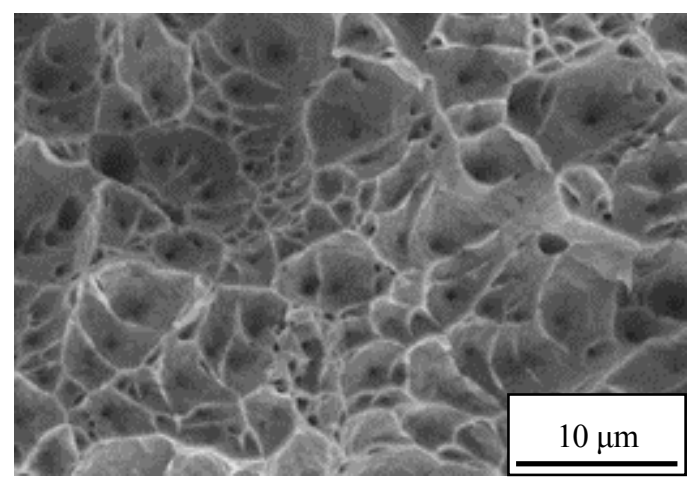

(a3) Magnification of $\mathrm{A}$

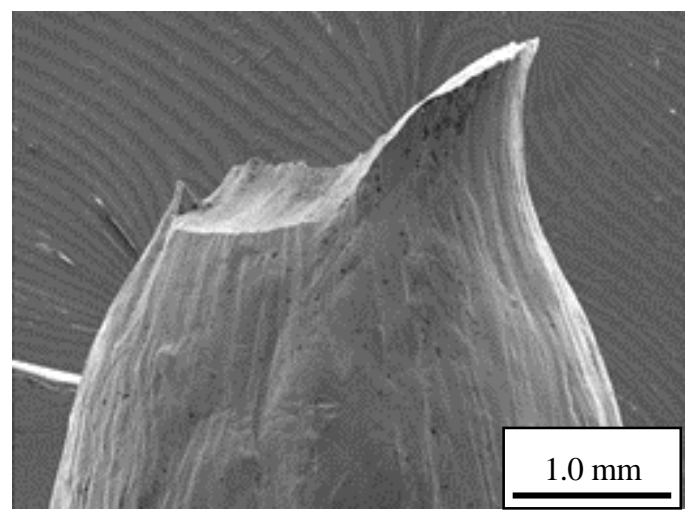

(a2) Side view

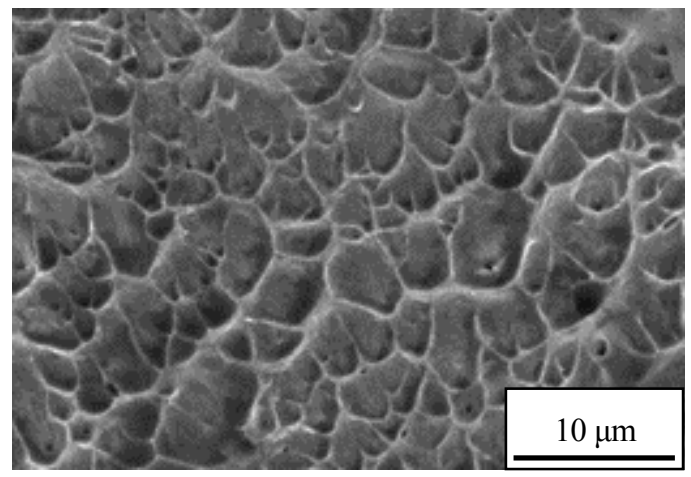

(a4) Magnification of B

(a) In $0.1 \mathrm{MPa}$ nitrogen gas at $-45{ }^{\circ} \mathrm{C}$

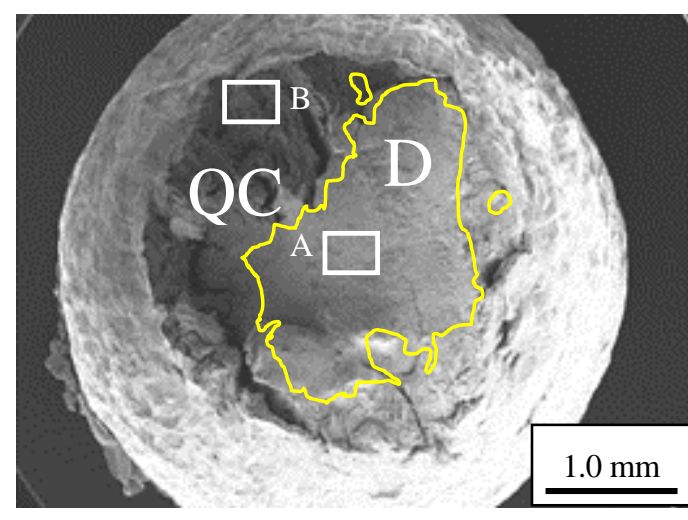

(b1) Top view

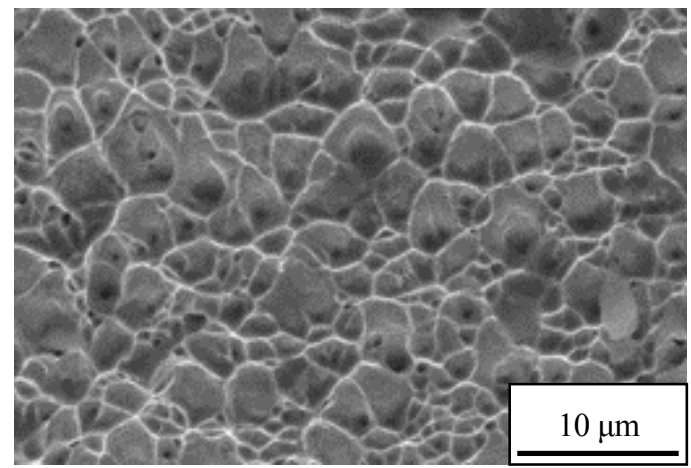

(b3) Magnification of A

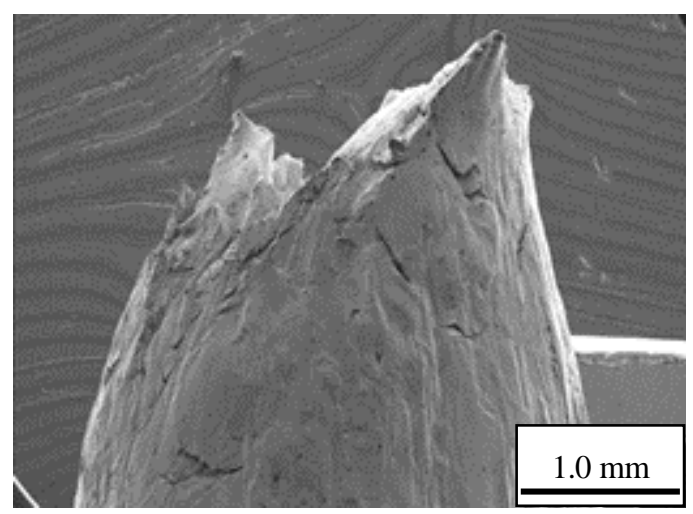

(b2) Side view

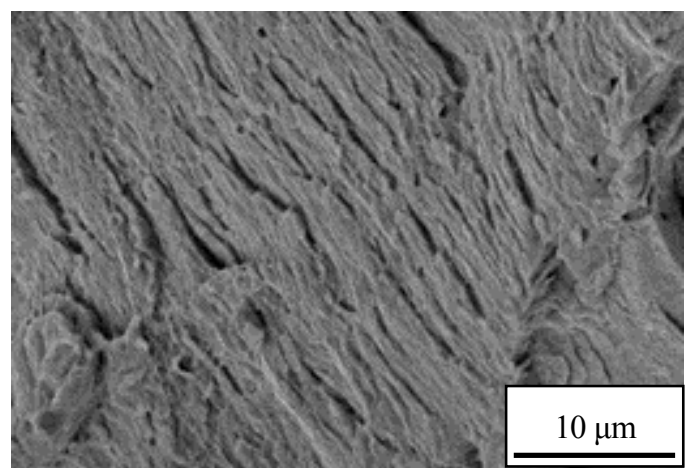

(b4) Magnification of B

(b) In106 MPa hydrogen gas at $-45{ }^{\circ} \mathrm{C}$

Fig. 14 SEM images of 316 post-welded solution-treated weld metal. The fracture surface was covered with dimples and quasi-cleavages. Additionally, secondary cracks existed on the surface of specimen. 


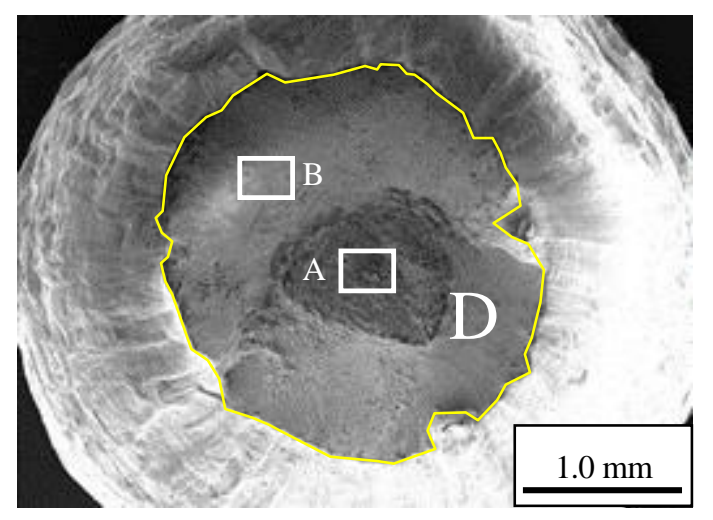

(a1) Top view

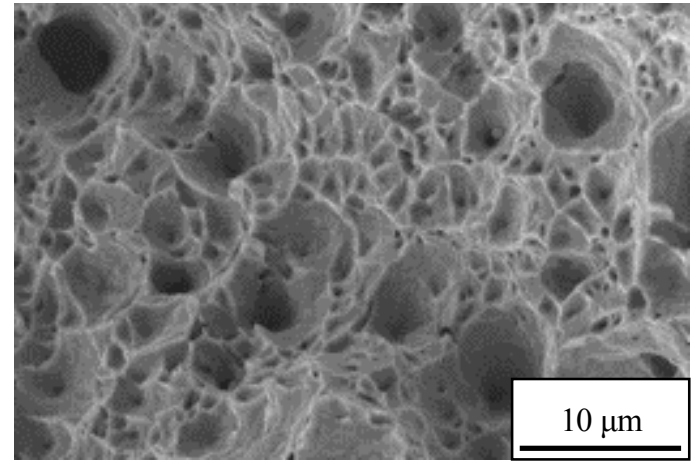

(a3) Magnification of A

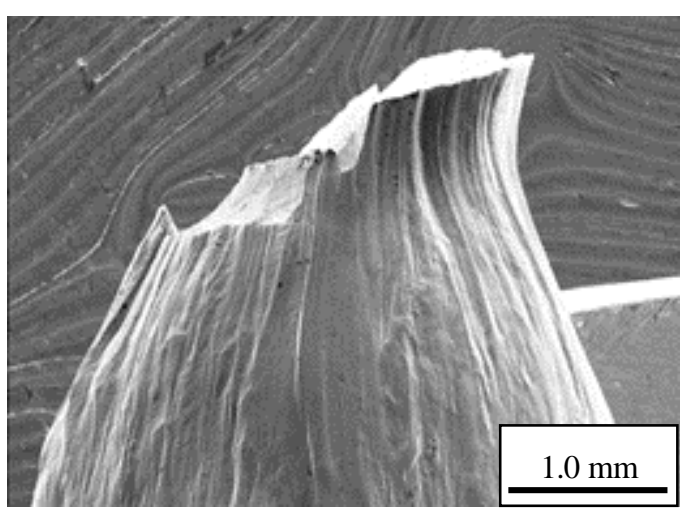

(a2) Side view

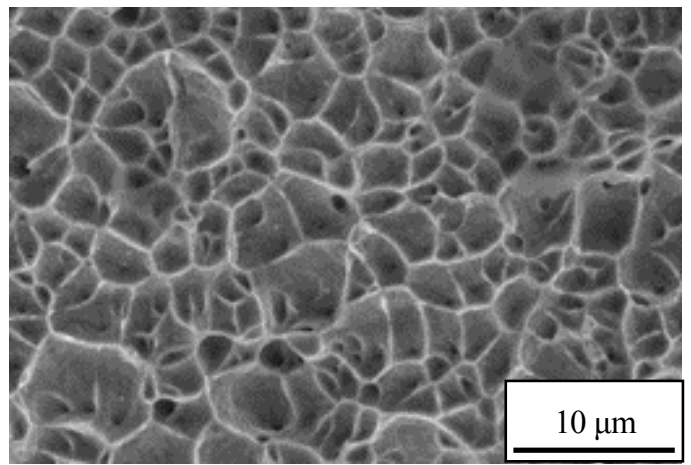

(a4) Magnification of B

(a) In $0.1 \mathrm{MPa}$ nitrogen gas at $-45{ }^{\circ} \mathrm{C}$

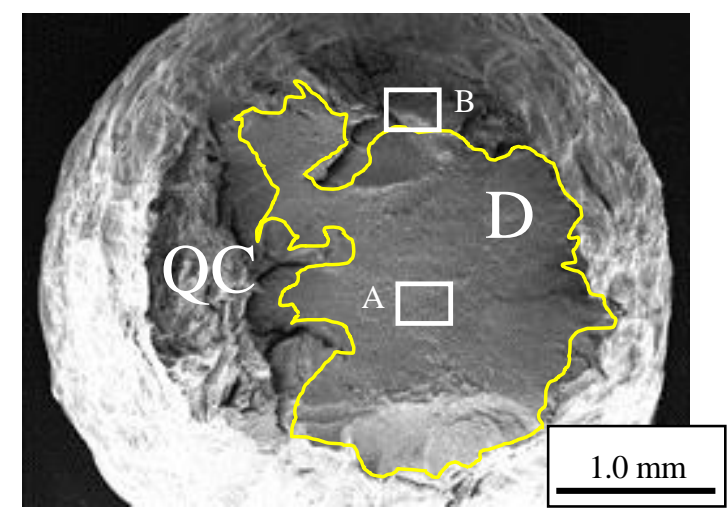

(b1) Top view

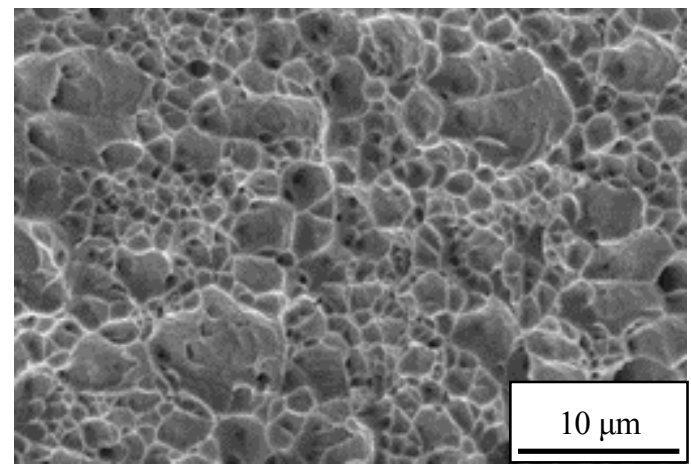

(b3) Magnification of A

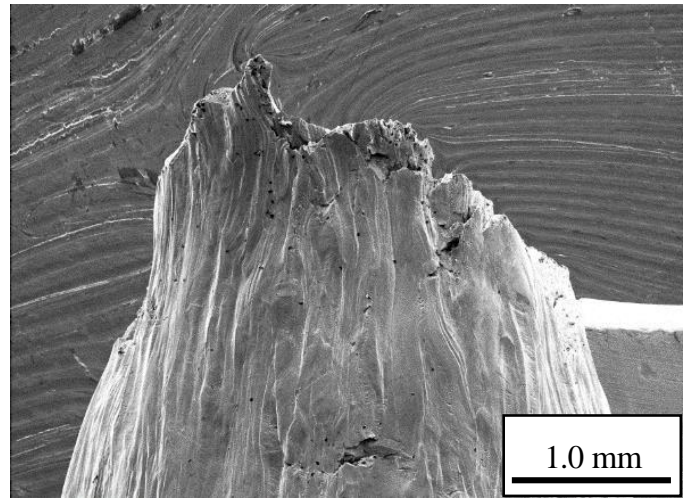

(b2) Side view

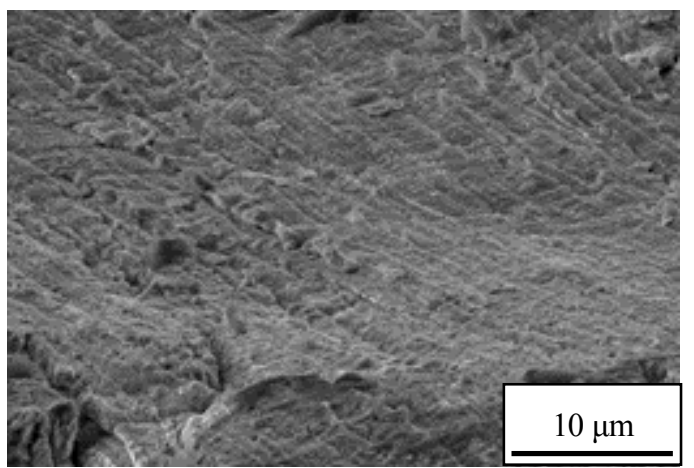

(b4) Magnification of B

(b) In106 MPa hydrogen gas at $-45{ }^{\circ} \mathrm{C}$

Fig. 15 SEM images of 316L post-welded solution-treated weld metal. The fracture surface was covered with dimples and quasi-cleavages. Additionally, secondary cracks existed on the surface of specimen. 


\section{$3 \cdot 4$ 相対絞りと $\mathrm{N}$ i 当量の関係}

一般高圧ガス保安規則の機能性基準の運用（平成 24 年 12 月 26 日）(高圧ガス協会，2011)において，「オース テナイト系ステンレス鋼 SUS316 と SUS316L であって, 規格材料の引張試験又はミルシートにおける絞りが $75 \%$ 以上，かつ $\mathrm{Ni}$ 当量が，その常用の温度が- $40{ }^{\circ} \mathrm{C}$ 以上 $-10{ }^{\circ} \mathrm{C}$ 未満である場合にあって 28.5 mass \%以上であるもの は, その常用の圧力が $70 \mathrm{MPa}$ 以下の水素ガス中で使用できる」ことが示された. この他に, Ni 当量が 27.4 mass \% と 26.3 mass \%の場合の運用についても示されている.

上述の $\mathrm{Ni}$ 当量が 28.5 mass \%以上である機能性基準の運用の見直しは次のようにして行われた(山田，小林， 2012). 文献調査を行って SUS304，SUS316，SUS316L の SSRT 試験データを集める. その中から選択した温度 $-123 \sim-40{ }^{\circ} \mathrm{C}$, 圧 $40 \sim 70 \mathrm{MPa}$ の水素ガス中の SSRT 試験データを相対絞り RRA と Ni 当量 Nieq の関係でプロ ットし，次式で近似する.

$$
\mathrm{RRA}=A+B \tanh [(\text { Nieq }-D) / C]
$$

ここで, $A=60, B=40, C=1.339, D=27.76$ である. Nieq は式(1)で計算する. 温度 $-123 \sim-40{ }^{\circ} \mathrm{C}$, 圧力 $40 \sim 70 \mathrm{MPa}$ の水素ガス中の RRA と Nieq の関係はほぼ一致するので, 式(2)を-40 ${ }^{\circ} \mathrm{C}, 70 \mathrm{MPa}$ 水素ガス中の試験結果に対す る近似式とする。得られた近似曲線を図 16 に実線で示す。

次に，水素の影響が少ないオーステナイト系ステンレス鋼の判定式として，次式を用いる(山田，小林，2012).

$$
\text { [引張試験又はミルシートの絞り }] \times R R A \geqq \text { 規格の絞り }
$$

上述の一般高圧ガス保安規則の機能性基準の運用(高圧ガス協会, 2011)では, SUS316 と SUS316L の引張試験で 得られた絞りまたはミルシートに記載の絞りが $75 \%$ 以上であることが要求されている．一方，JIS 規格では， SUS316 と SUS316Lの絞りは $60 \%$ 以上であることが要求される. $75 \%$ と $60 \%$ の絞りを式(3)に代入すると, RRA $\geqq$ 0.8 となる. RRA $\geqq 0.8$ と式(2)（図 16 の実線）から，上述の機能性基準の運用(高圧ガス協会，2011)で示された Nieq $\geqq 28.5$ mass \%が得られる. 寸なわち，機能性基準の運用の見直し前は，RRA $\fallingdotseq 1.0$ となる水素の影響が ない材料の使用しか認められていなかったが，機能性基準の運用の見直し後では，RRA ミ0.8を満たす材料が 水素の影響が少ない材料として認められたことになる.

以上をもとに，オーステナイト系ステンレス溶接金属の水素脆性を検討すると，次のようになる.

(1) 図 8 に示したように, 表 1 で Nieq = 29.69 mass \%の SUS316（hi-Ni）母材試験片の絞りは $-45{ }^{\circ} \mathrm{C} ・ 0.1 \mathrm{MPa}$ 窒素ガス中で $\varphi_{\mathrm{N}}=83 \%,-45{ }^{\circ} \mathrm{C} ・ 106 \mathrm{MPa}$ 水素ガス中では $\varphi_{\mathrm{H}}=85 \%$ であった. その結果, 相対絞りは RRA $=1.02$ となり, 図 16 においてRRA と Nieq の関係（口）は実線の近似式と一致した. したがって, SUS316 (hi-Ni) 母材は機能性基準の運用(高圧ガス協会，2011)の要求を満たす.

(2) 図 9 に示したように，317L 溶接まま試験片の絞りは－ $45{ }^{\circ} \mathrm{C} ・ 0.1 \mathrm{MPa}$ 窒素ガス中で $\varphi_{\mathrm{N}}=58 \%$ あっった. こ の值は機能性基準の運用(高圧ガス協会, 2011)で要求される引張試験における絞り $75 \%$ より 小さい. $-45{ }^{\circ} \mathrm{C} \cdot 106 \mathrm{MPa}$ 水素ガス中では絞りは $\varphi_{\mathrm{H}}=32 \%$ とさらに小さい. その結果, 相対絞りは RRA $=0.55$ とな り, RRA $\geqq 0.8$ を満足しない. また，図 16 に $317 \mathrm{~L}$ 溶接まま試験片の RRA と Nieq の関係をの記号で示す が，実線の近似曲線の下側に大きく外れている。したがって，溶接状態ままの $317 \mathrm{~L}$ 溶接金属は，水素ガス中 のみならず, 窒素ガスのような不活性ガス中においても機能性基準の運用(高圧ガス協会, 2011)の要求を満た さない.

(3) 図 10 に示したように, $317 \mathrm{~L}, 316,316 \mathrm{~L}$ 溶体化試験片の絞りは, $-45{ }^{\circ} \mathrm{C} \cdot 0.1 \mathrm{MPa}$ 窒素ガス中では $\varphi_{\mathrm{N}} \geqq 84 \%$, $-45{ }^{\circ} \mathrm{C} \cdot 106 \mathrm{MPa}$ 水素ガス中では $\varphi_{\mathrm{H}} \geqq 73 \%$ であた. その結果, 相対絞りはRRA $\geqq 0.87$ となり, 図 16 に示寸ように，317L，316，316L 溶体化引張試験片の RRA と Nieq の関係 $(\bullet ， \Delta$ ， は) は実線の近似曲線 とよく一致した。したがって，溶接後に溶体化熱処理を施した $317 \mathrm{~L} ， 316 ， 316 \mathrm{~L}$ 溶接金属は，機能性基準の 運用(高圧ガス協会, 2011)の要求を満たし, ほとんど水素による延性低下を起こさないと結論できる. なお, 図 13〜15 に示した破面の SEM 像からは, 3 つの溶接金属のうちで $317 \mathrm{~L}$ 溶接金属が最も優れた耐水素性を有 
することがわかる．Ni 当量が最も高い 317L 溶体化試験片では，破面には擬へき開領域が形成されず，かつ 試験片表面には 2 次き裂が残っていない（図 13).

以上の検討から，次のことが期待できる． Ni 当量が 28.5 mass \%以上である SUS316 製パイプを $\mathrm{Ni}$ 当量が 28.5 mass \%以上である 317L 溶加材を用いて溶接する．溶接されたパイプに溶体化熱処理を施す．このようにして製 造したパイプ溶接継手は, 水素ステーションで想定される最低温度と設計圧力の組み合わせ, すなわちー $45{ }^{\circ} \mathrm{C} \cdot$ 106 MPa の水素ガス中でもほとんど水素脆化しない．溶接後の溶体化熱処理で水素脆化の懸念を取り除いたパイ プ溶接継手の使用により，水素ステーションの安全性を確保しつつ，機械継手であるコーンアンドスレッド継手 で懸念される水素ガス漏洩も払拭できる. 水素ステーションで使用される部材には比較的小型のものが多いため, 溶体化熱処理が容易に実施できることも本手法のメリットである.

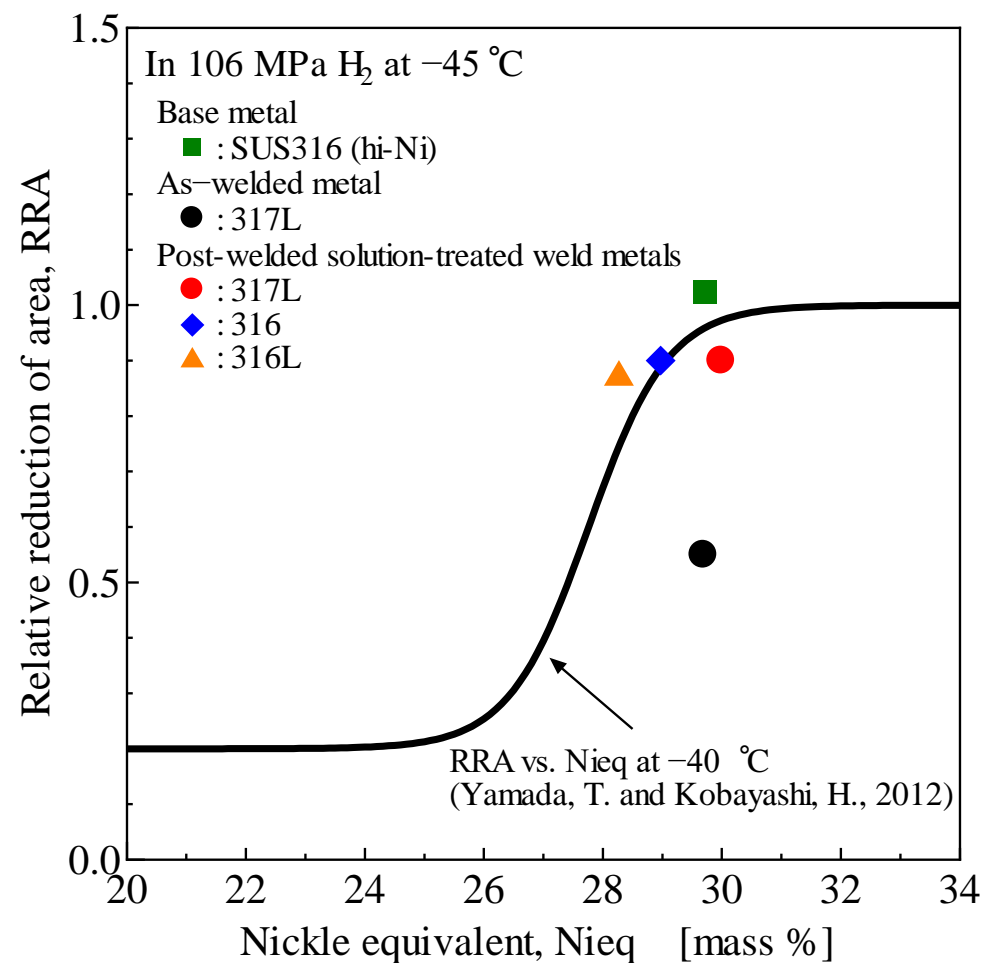

Fig. 16 Relationship of relative reduction of area, RRA, and nickel equivalent, Nieq. SSRT properties of 317L, 316 and 316L post-welded solution-treated weld metals were well consistent with the approximate curve on the relationship of RRA and Nieq, which was concluded that 317L, 316 and 316L weld metals caused little or no hydrogen embrittlement by post-welded solution-treatment.

\section{4. 結 言}

オーステナイト系ステンレス鋼の母材 SUS316 (hi-Ni) (Nieq = 29.69 mass \%) に3 種類の溶加材 317L (Nieq = 29.99 mass \% ） $316 （$ Nieq = 28.97 mass \% ）３16L（Nieq = 28.27 mass \%）を用いて TIG 溶接を行い，多層肉盛溶接材を 作成した. 多層肉盛溶接材から試験部全体（直径 $6 \mathrm{~mm}$, 平行部長さ $30 \mathrm{~mm}$ ）が溶接金属である引張試験片を作 製した. 上記の 1 種類の母材と 3 種類の溶接金属の低歪速度引張試験（SSRT）を，水素ステーションで想定され る最低温度と設計圧力の組み合わせである $-45{ }^{\circ} \mathrm{C} ・ 106 \mathrm{MPa}$ の水素ガス中で実施し, 結果を $-45{ }^{\circ} \mathrm{C} ・ 0.1 \mathrm{MPa}$ 窒素ガス中での試験結果と比較した，得られた結論は次の通りである.

(1) SUS316（hi-Ni）母材の絞りは, $-45{ }^{\circ} \mathrm{C} \cdot 0.1 \mathrm{MPa}$ 窒素ガス中で $\varphi_{\mathrm{N}}=83 \%,-45{ }^{\circ} \mathrm{C} \cdot 106 \mathrm{MPa}$ 水素ガス中で $\varphi_{\mathrm{H}}=85$ \%となり, 結果として相対絞りはRRA=1.02 となった. 寸なわち, SUS316（hi-Ni）母材は水素脆化 せず，見直された一般高圧ガス保安規則の機能性基準の運用（平成 24 年 12 月 26 日）(高圧ガス協会，2011) の要求を満たした. 
(2) 溶接状態ままの $317 \mathrm{~L}$ 溶接金属の絞りは， $-45{ }^{\circ} \mathrm{C} \cdot 0.1 \mathrm{MPa}$ 窒素ガス中では $\varphi_{\mathrm{N}}=58 \%,-45{ }^{\circ} \mathrm{C} \cdot 106 \mathrm{MPa}$ 水素ガス中では $\varphi_{\mathrm{H}}=32 \%$ となり， RRA $=0.55$ となった．すなわち，溶接ままの 317L 溶接金属は著しく水素 脆化し，見直された一般高圧ガス保安規則の機能性基準の運用 (平成 24 年 12 月 26 日) (高圧ガス協会, 2011) の要求を満たすことができなかった.

（3）溶接後に溶体化熱処理した 317L，316，316L 溶接金属の絞りは， $-45{ }^{\circ} \mathrm{C} ・ 0.1 \mathrm{MPa}$ 窒素ガス中では $\varphi_{\mathrm{N}}=84 \%$ 以上, $-45{ }^{\circ} \mathrm{C} \cdot 106 \mathrm{MPa}$ 水素ガス中では $\varphi_{\mathrm{H}}=73 \%$ 以上となり, 結果として相対絞りはそれぞれ $\mathrm{RRA}=0.90$, 0.90，0.87 となった. すなわち，溶接後に溶体化熱処理した 317L，316，316L 溶接金属はほとんど水素脆化 せず，見直された一般高圧ガス保安規則の機能性基準の運用（平成 24 年 12 月 26 日）(高圧ガス協会，2011) の要求を満たした。

(4) $-45{ }^{\circ} \mathrm{C} \cdot 106 \mathrm{MPa}$ 水素ガス中において，溶体化熱処理した 317L 溶接金属の破面にはディンプル領域のみが 形成され，試験片表面には 2 次き裂が存在しなかった。一方，溶体化熱処理した 316，316L 溶接金属の破面 にはディンプル領域に加えて擬へき開領域が形成され，試験片表面には 2 次き裂が残存していた。このこと から， Ni 当量が最も高い 317L 溶接金属が最も優れた耐水素性を有することが明らかになった.

以上の結果から, $\mathrm{Ni}$ 当量が 28.5 mass \%以上のオーステナイト系ステンレス鋼製パイプに溶加材 317L を用いて 溶接し, 溶接後に溶体化熱処理を施すことにより，水素ステーションで水素脆化の懸念と水素漏洩の懸念の両方 を払拭したパイプ溶接継手が使用でき，水素ステーションの安全性が格段に向上することが期待できる.

\section{謝辞}

本研究の一部は，国立研究開発法人 新エネルギー・産業技術総合開発機構（NEDO）の「水素ステーション用 金属材料の鋼種拡大に関する研究開発」（平成 25 年度〜29 年度）の一環として行われたものである.

\section{文献}

ASTM G 142, Standard Test Method for Determination of Susceptibility of Metals to Embrittlement in Hydrogen Containing Environments at High Pressure, High Temperature, or Both(2011).

Brooks, J. A. and West, J., Hydrogen Induced Ductility Losses in Austenitic Stainless Steel Welds, Metallurgical Transactions A, Vol.12A (1981), pp.213-223.

平田弘征，大村朋彦，浄徳佳奈，中村 潤，小薄孝裕，高圧水素ガス環境下におけるオーステナイト系ステンレ ス鋼溶接金属の水素脆化に及ぼす化学成分および組織の影響, 溶接学会論文集, Vol.31, No.4 (2013), pp. $216-251$.

平山俊成, 小切間雅彦, Fe-Ni 系マルテンサイト変態に対する化学組成の影響, 日本金属学会誌, Vol.34 (1970), pp.507-510.

井藤賀久岳，松尾尚，織田章宏，松永久生，松岡三郎，高圧水素ガス中における 2 種類の高強度オーステナイト 系ステンレス鋼の SSRT 特性と疲労き裂進展特性, 日本機械学会論文集 A 編, Vol.79, No.808 (2013), pp.1726-1740.

Jackson, H. F., Nibur, K. A., Marchi, C. S., Puskar, J. D. and Somerday, B. P., Hydrogen-assisted crack propagetaion in 304L/308L and 21Cr-6Ni-9Mn/308L austenitic stainless steel fusion welds, Corrosion Science, Vol.60 (2012), pp.136-144.

JIS G 4303，ステンレス鋼棒(2014).

Marchi, C. S., Michler T., Nibur, K. A. and Somerday, B. P., On the Physical Differences between Tensile Testing of Type 304 and 316 Austenitic Stainless Steels with Internal Hydrogen and in External Hydrogen, International Journal of Hydrogen Energy, Vol.35, No.18 (2010), pp.9736-9745.

Matsunaga, H., Kondo, R., Yamabe, J., Yoshikawa, M., Itoga, H. and Matsuoka, S., Hydrogen-assisted cracking of Cr-Mo Steel in Slow Strain Rate Tensile Test With high-pressure gaseous hydrogen, American Society of Mechanical Engineers, Pressure Vessels and Piping Division (Publication) PVP (2015a), Paper No. PVP2015-45742.

Matsunaga, H., Yoshikawa, M., Kondo, R., Yamabe, J. and Matsuoka, S., Slow strain rate tensile and fatigue properties of Cr-Mo and carbon steels in a $115 \mathrm{MPa}$ hydrogen gas atmosphere, International Journal of Hydrogen Energy, Vol.40 (2015b), pp.5739-5748. 
Matsuoka, S., Yamabe, J. and Matsunaga, H., Criteria for determining hydrogen compatibility and the mechanisms for hydrogen-assisted, surface crack growth in austenitic stainless steels, Engineering Fracture Mechanics, Vol.153 (2016), pp.103-127.

NEDO 水素エネルギー白書 2014, 独立行政法人 新エネルギー・産業技術総合開発機構(2014).

Somerday, B. P., Dadfarnia, M., Balch, D. K., Nibur, K. A., Cadden, C. H. and Sofronis, P., Hydrogen-Assisted Crack Propagation in Austenitic Stainless Steel Fusion Welds, Metallurgical and Materials Transactions A, Vol.40A (2009), pp.2356-2362.

特定設備検査規則関係例示基準集＼cjkstart第 3 次改訂版，高圧ガス協会(2011).

Walter, R. J. and Chandler, W. T., Effects of High Pressure on Metals, the 1968 Materials Engineering Exposition \& Congress, American Society for Metals(1968).

山田敏弘, 小林英男, 水素ステーション設備に使用する材料の選定基準, 高圧ガス, Vol.49, No.10 (2012), pp.885-893.

\section{References}

ASTM G 142, Standard Test Method for Determination of Susceptibility of Metals to Embrittlement in Hydrogen Containing Environments at High Pressure, High Temperature, or Both(2011).

Brooks, J. A. and West, J., Hydrogen Induced Ductility Losses in Austenitic Stainless Steel Welds, Metallurgical Transactions A, Vol.12A (1981), pp.213-223.

Hirata, H., Omura, T., Jotoku, K., Nakamura, J. and Osuki, T., Effects of Chemical Compositions and Microstructure on Hydrogen Embrittlement of Austenitic Stainless Steel Weld Metal in High Pressure Gaseous Hydrogen Environment, Quarterly Journal of the Japan Welding Society, Vol.31, No.4(2013), pp.216-251 (in Japanese).

Hirayama, T. and Ogirima, M., Influence of Chemical Composition on Martensitic Transformation in Fe-Cr-Ni Stainless Steel, J. Japan Inst. Met. Mater, Vol.34, No.5 (1970), pp.507-510 (in Japanese).

Itoga, H., Matsuo, T., Orita, A., Matsunaga, H. and Matsuoka, S., SSRT and Fatigue Crack Growth Properties of Two Types of High Strength Austenitic Stainless Steels in High Pressure Hydrogen Gas, Transactions of the Japan Society ofMechanical Engineers, Serise A, Vol.79, No.808 (2013), pp.1726-1740 (in Japanese).

Jackson, H. F., Nibur, K. A., Marchi, C. S., Puskar, J. D. and Somerday, B. P., Hydrogen-assisted crack propagetaion in 304L/308L and 21Cr-6Ni-9Mn/308L austenitic stainless steel fusion welds, Corrosion Science, Vol.60 (2012), pp.136-144.

JIS G 4303, Stainless steel bars(2014) (in Japanese).

Marchi, C. S., Michler T., Nibur, K. A. and Somerday, B. P., On the Physical Differences between Tensile Testing of Type 304 and 316 Austenitic Stainless Steels with Internal Hydrogen and in External Hydrogen, International Journal of Hydrogen Energy, Vol.35, No.18 (2010), pp.9736-9745.

Matsunaga, H., Kondo, R., Yamabe, J., Yoshikawa, M., Itoga, H. and Matsuoka, S., Hydrogen-assisted cracking of Cr-Mo Steel in Slow Strain Rate Tensile Test With high-pressure gaseous hydrogen, American Society of Mechanical Engineers, Pressure Vessels and Piping Division (Publication) PVP (2015a), Paper No. PVP2015-45742.

Matsunaga, H., Yoshikawa, M., Kondo, R., Yamabe, J. and Matsuoka, S., Slow strain rate tensile and fatigue properties of $\mathrm{Cr}-\mathrm{Mo}$ and carbon steels in a $115 \mathrm{MPa}$ hydrogen gas atmosphere, International Journal of Hydrogen Energy, Vol.40 (2015b), pp.5739-5748.

Matsuoka, S., Yamabe, J. and Matsunaga, H., Criteria for determining hydrogen compatibility and the mechanisms for hydrogen-assisted, surface crack growth in austenitic stainless steels, Engineering Fracture Mechanics, Vol.153 (2016), pp.103-127.

NEDO suiso enerugi hakusyo 2014, The New Energy and Industrial Technology Development Organization (2014) (in Japanese).

Somerday, B. P., Dadfarnia, M., Balch, D. K., Nibur, K. A., Cadden, C. H. and Sofronis, P., Hydrogen-Assisted Crack Propagation in Austenitic Stainless Steel Fusion Welds, Metallurgical and Materials Transactions A, Vol.40A (2009), pp.2356-2362.

Tokutei setsubi kensa kisoku kankei reiji kijunsyu dai 3 ji kaiteiban, The High Pressure Gas Safety Institute of Japan (2011) (in Japanese).

Walter, R. J. and Chandler, W. T., Effects of High Pressure on Metals, the 1968 Materials Engineering Exposition \& Congress, American Society for Metals(1968). 
Matsuoka, Sato, Yamaguchi, Hamada, Nakamura and Matsunaga,

Transactions of the JSME (in Japanese), Vol.82, No.839 (2016)

Yamada, T. and Kobayashi, H., Suiso suteisyon ni siyou suru zairyou no sentei kijun, The High Pressure Gas Safety Institue of Japan, Vol.49, No.10 (2012), pp.885-893 (in Japanese). 